The Geological Society of America

Digital Map and Chart Series 12

\title{
Geologic Map of the Central Grapevine Mountains, Inyo County, California, and Esmeralda and Nye Counties, Nevada
}

\author{
Nathan A. Niemi* \\ Department of Earth and Environmental Sciences, University of Michigan, Ann Arbor, Michigan 48109, USA
}

\begin{abstract}
Over $8000 \mathrm{~m}$ of Proterozoic through Quaternary strata are exposed in the central Grapevine Mountains. The lower $5500 \mathrm{~m}$ comprises Neoproterozoic and Paleozoic strata, with the lowermost $1850 \mathrm{~m}$ representing primarily siliciclastic rift strata, and the overlying $3650 \mathrm{~m}$ composed predominantly of dolomite and limestone with thinly interbedded sandstones and shales of the Cordilleran passive margin sequence. The upper $2500 \mathrm{~m}$ of strata is late Cenozoic in age, and is composed principally of ash flow tuffs and lavas related to the southwest Nevada volcanic field, but also includes fluvial and lacustrine deposits.

The core of the range exposes an east directed thrust and a west directed fold resulting from late Paleozoic contraction within the Death Valley thrust belt. The Titus Canyon anticline (Reynolds, 1969) trends northwesterly across the entire range, transferring strain northwards into a west directed thrust system. The Grapevine thrust (Reynolds, 1974) is found at the western edge of the range, and places Proterozoic Stirling Quartzite on rocks as young as Mississippian. The large stratigraphic throw across this fault suggests that the Grapevine thrust is a remnant of the Last Chance thrust, a regionally extensive thrust sheet identified throughout the Death Valley area.

The flanks of the range are bounded by Cenozoic structures. To the east, the Fall Canyon fault zone separates Paleozoic marine strata on the west from Miocene volcanic rocks associated with the Southwest Nevada volcanic field. This structure was active in middle to late Miocene time. To the west, the Grapevine Mountains are bounded by the northern Death Valley fault zone, an active dextral strike-slip fault that accommodates Pacific-North America plate motion in the Eastern California Shear Zone.
\end{abstract}

\section{INTRODUCTION}

The Grapevine Mountains lie at the northeastern margin of Death Valley, California, near the western edge of the Great Basin physiographic province. The range straddles the CaliforniaNevada border, as well as the Death Valley National Park boundary, and covers portions of Inyo County California, and Nye and

*naniemi@umich.edu
Esmeralda counties, Nevada. The range rises from $300 \mathrm{~m}$ on the floor of Death Valley to $2550 \mathrm{~m}$ at the top of Grapevine Peak. This study covers the central portion of the range, extending from Titus Canyon in the south to Scotty's Castle and Grapevine Canyon in the north (Fig. 1). Geologic studies that cover adjacent or proximal areas are shown on Figure 2.

Mapping was conducted at scales of 1:12,000 and 1:24,000 both on topographic base maps and on conventional and digital aerial photographs from 1996 to 2000. This mapping was

Niemi, N.A., 2012, Geologic Map of the Central Grapevine Mountains, Inyo County, California, and Esmeralda and Nye Counties, Nevada: Geological Society of America Digital Map and Chart Series 12, doi: 10.1130/2012.DMCH012. For permission to copy, contact editing @ geosociety.org. @2012 The Geological Society of America. All rights reserved. 
Figure 1. Place names used in the discussion of the geology of the Grapevine Mountains.

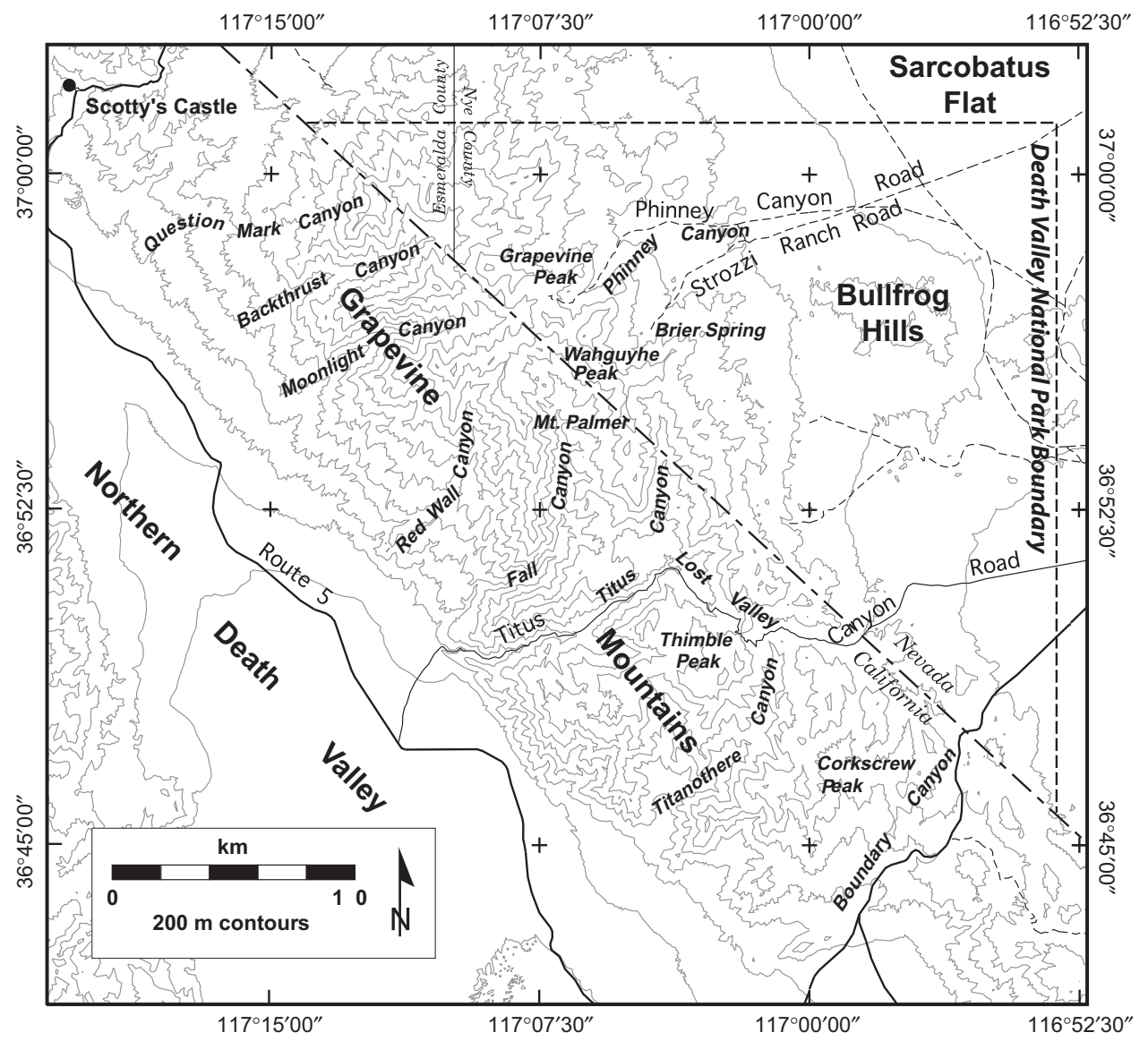

compiled with mapping from the Titus Canyon and Lost Valley areas (Figs. 1 and 2; Reynolds, 1969; C.J. Fridrich, unpublished mapping) at a scale of 1:48,000.

Few place names exist in the Grapevine Mountains, thus several informal names are introduced to make discussion of the geology in the Grapevine Mountains more straightforward. Two major east-west-trending canyons bisect the central portion of the Grapevine Mountains. The southern canyon is called "Moonlight Canyon," after previous informal usage (Fig. 1; Gebhardt and Willis, 1996). The northernmost of these two canyons is named "Backthrust Canyon" (Fig. 1) for exposures of a westvergent thrust system on the northern wall of the canyon. At the northern end of the range, a long canyon, which cuts through several important outcrops, is named "Question Mark Canyon" for its shape in map view (Fig. 1).

\section{PROTEROZOIC AND PALEOZOIC STRATIGRAPHY}

Neoproterozoic rift-fill strata and Paleozoic strata of the Cordilleran miogeocline constitute the core of the Grapevine Mountains (Fig. 3). Structurally, the Grapevine Mountains appear to be a north tilted fault block, such that, as a general rule, pre-Cenozoic strata young from south to north. The oldest strata in the Grapevine Mountains are exposed along the southern edge of the range in Boundary Canyon, while the youngest Paleozoic strata are exposed at the northern end of the range, near Scotty's Castle. Neoproterozoic strata are exposed throughout the southern Grapevine Mountains (Reynolds, 1969). The lowest Neoproterozoic strata in the range are best exposed, and most accessible, just to the north of the Daylight Pass Road, east of Daylight Pass (Fig. 4; Wright and Troxel, 1993; C.J. Fridrich, unpublished mapping). Upper Neoproterozoic strata and Lower to Middle Cambrian strata are exposed along the Titus Canyon Road, beginning $\sim 3 \mathrm{~km}$ south of Leadfield, although the strata are inverted at this locale (Fig. 4; Reynolds, 1969). Exposures of Middle and Upper Cambrian strata are well exposed on both the west and east sides of the ridge south of Mt. Palmer; however, these exposures are largely inaccessible. Sections of Ordovician and Devonian strata are also exposed in the Grapevine Mountains, particularly in upper Red Wall Canyon; however, access to these sections requires a $6.5 \mathrm{~km}$ hike from the top of Phinney Canyon. Mississippian strata are exposed in the northwestern portion of the range, and are reached only on foot via an $\sim 11$ km hike (Fig. 4).

Neoproterozoic and Cambrian rocks in the Grapevine Mountains are mainly shallow water shelf and continental slope facies strata, deposited on what was then the passive margin of western North America. These deposits are divisible into two sequences, including a west-thickening wedge of shallow-water clastic strata 


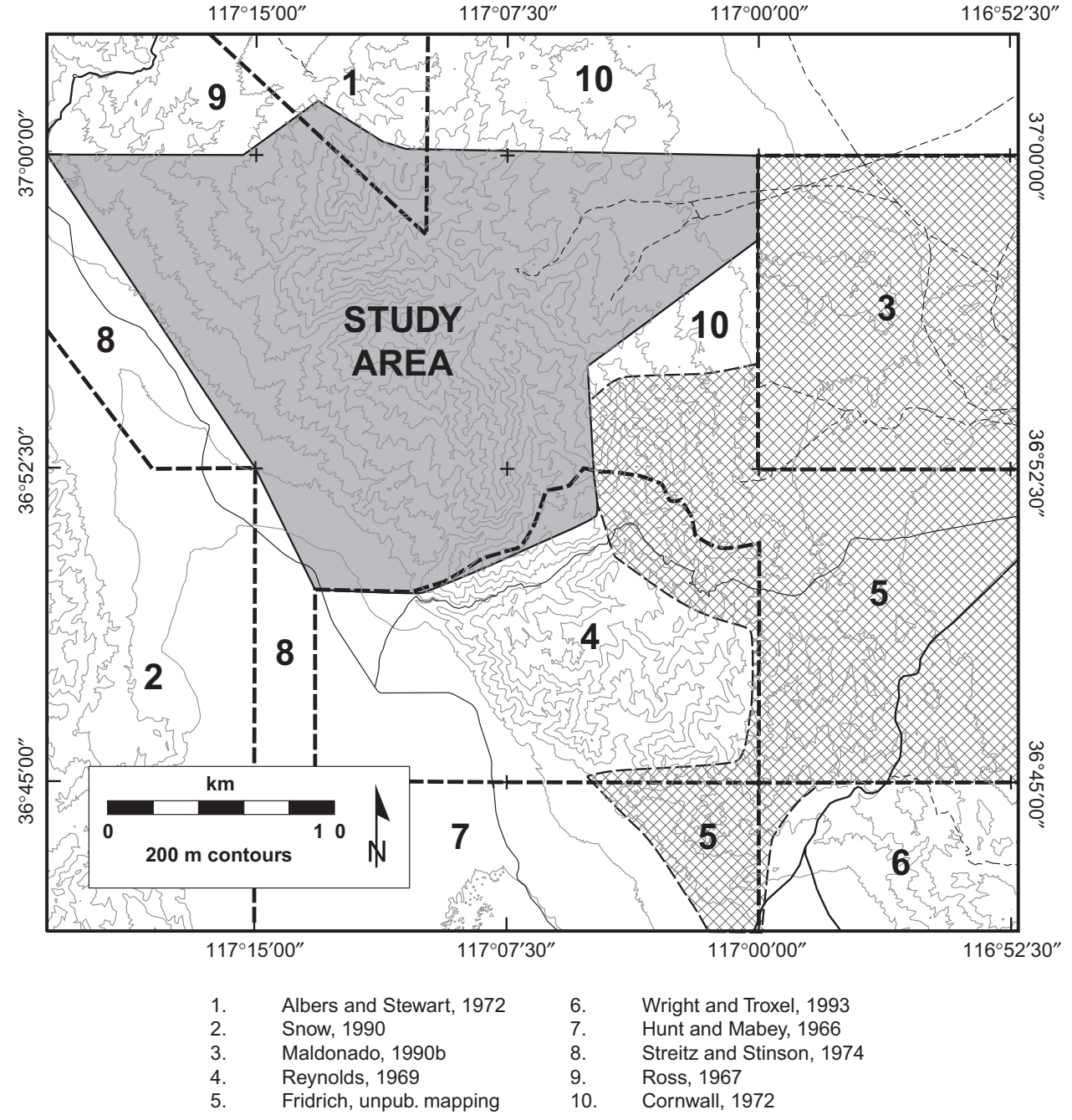

Figure 2. Index of geologic mapping in the Grapevine Mountains area. of late Neoproterozoic and early Cambrian age, and shallow water carbonate strata of Middle and Upper Cambrian age (e.g., Stewart and Suczek, 1977). Shallow water deposition of carbonates continued through most of Ordovician, Silurian, and Devonian time (e.g., Ross, 1977; Poole et al., 1977). In Late Devonian to Early Mississippian time, deformation associated with the Antler Orogeny caused a reorganization of depositional systems across the western United States, resulting in significant lateral facies changes from west to east across the continental margin (e.g., Poole and Sandberg, 1977). An understanding of these facies changes is important for paleogeographic reconstructions in the Death Valley region; however, stratigraphic complexities resulting from these facies changes make correlation between various Mississippian sections complicated (e.g., Stone, 1984; Stevens, 1986; Trexler et al., 1996).

\section{Zs-Stirling Quartzite}

The Stirling Quartzite was named by Nolan (1929) for exposures at Mt. Stirling, in the Spring Mountains. It has subsequently been described throughout the Death Valley region by Stewart
(1970), who divided the unit into five informal members, designated, stratigraphically lowest to highest, A through E. Members $\mathrm{C}$ and D are present in the southwestern Grapevine Mountains (Wright and Troxel, 1993; C.J. Fridrich, unpublished mapping), while unit $\mathrm{E}$ is present in several localities throughout the southern and central Grapevine Mountains. Members A and B are not present in the Grapevine Mountains, but are exposed in the Funeral Mountains, to the south.

At its type section, $1128 \mathrm{~m}$ of Stirling Quartzite is reported (Nolan, 1929). A lesser thickness, $790 \mathrm{~m}$, is reported for the Nopah Range (Hazzard, 1937). Incomplete sections of the Stirling Quartzite closer to the Grapevine Mountains, at Bare Mountain, and at Lees Camp in the Funeral Mountains, yield thicknesses of 588 and $765 \mathrm{~m}$, respectively, while a complete section at Echo Canyon in the Funeral Mountains measured 1451 m (Stewart, 1970).

\section{Zsc-C Member}

The lowest member of the Stirling Quartzite exposed in the Grapevine Mountains, the $\mathrm{C}$ member, comprises siltstone in its lower part and quartzite in the upper part. The siltstone 


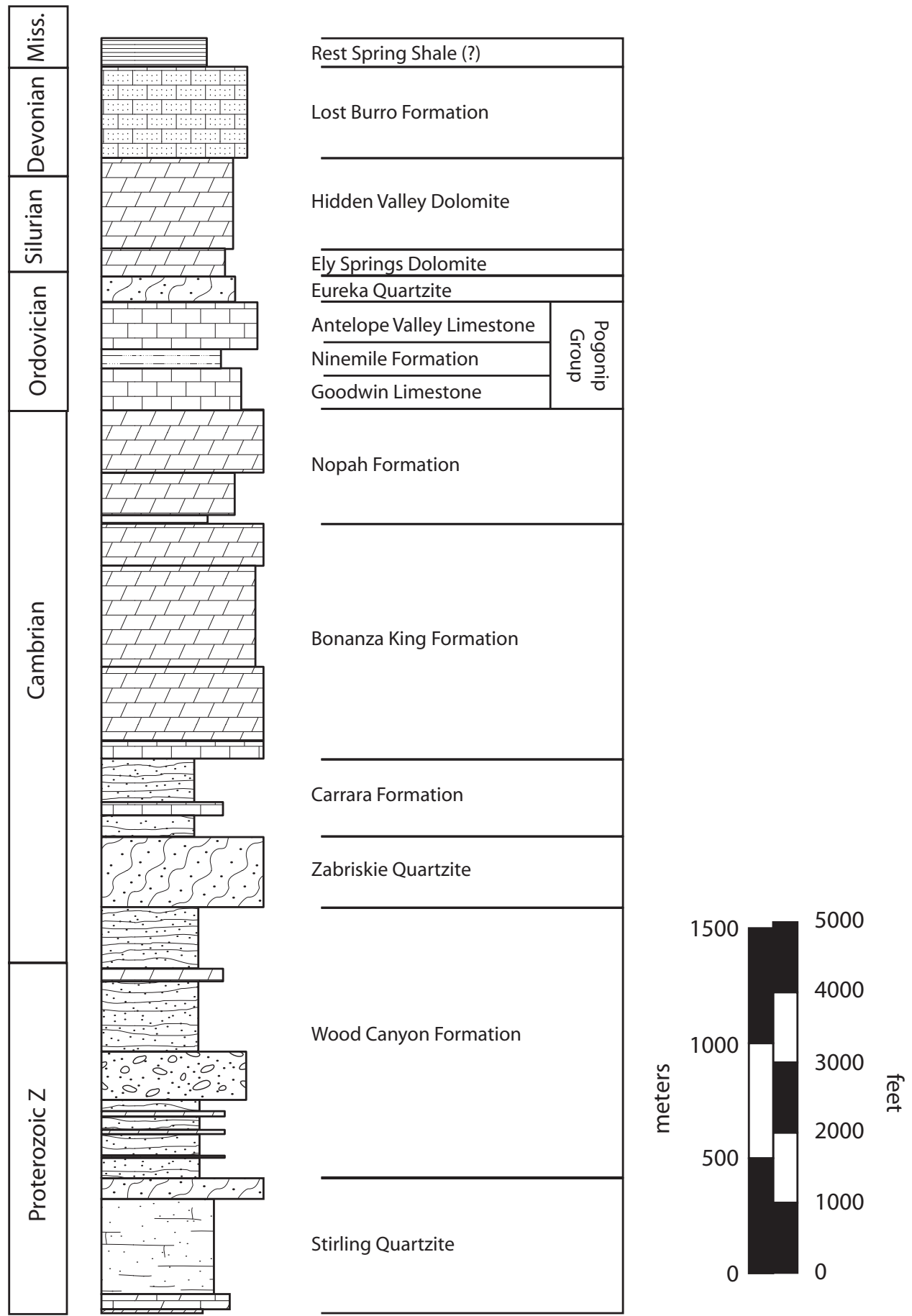

Figure 3. Generalized stratigraphic section of Proterozoic Z through Mississippian strata exposed in the Grapevine Mountains.

is commonly greenish-gray or light-olive-gray to grayish-red, while the quartzite is pale-red, grayish-red or yellowish-gray (Stewart, 1970). The base of the Stirling C member is nowhere exposed, while the top is marked by the transition from quartzite of the $\mathrm{C}$ member to the dolostone and limestone of the $\mathrm{D}$ member.

\section{Zsd-D Member}

The D member of the Stirling Quartzite consists of finely crystalline laminated dolostone and limestone in the lower half and siltstone, fine quartzite, and dolostone in the upper half (Stewart, 1970). The upper contact of the D member is taken at the base of a large, cliff-forming quartzite. 


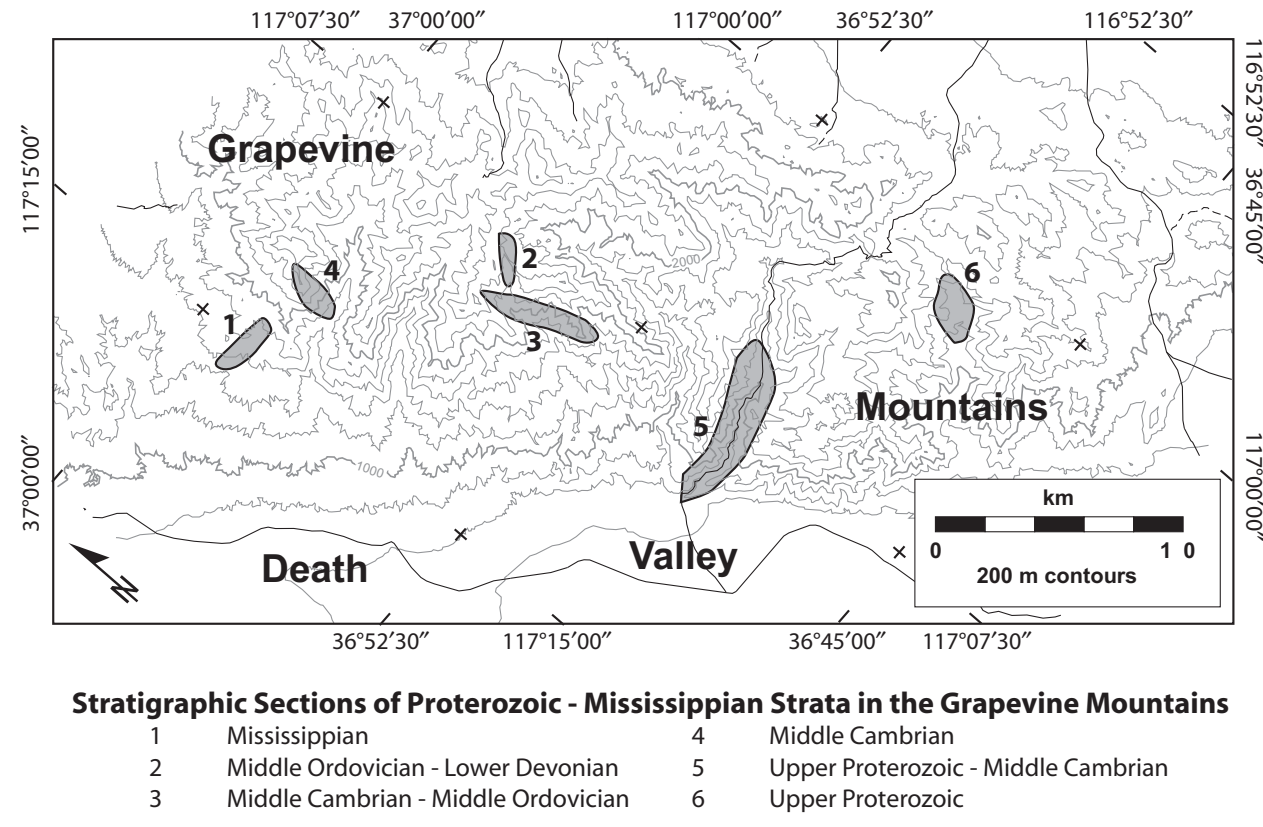

Figure 4. Topographic map of the Grapevine Mountains showing locations of relatively complete stratigraphic sections of Proterozoic Z through Mississippian strata (gray regions) and roads that can be used to access the area (black lines).

\section{Zse-E Member}

The E member of the Stirling Quartzite is composed of pinkish-gray to yellowish-gray medium- to coarse-grained quartzite. The unit is tightly cemented, weathers a rusty brown, and is a cliff former in many locations (Reynolds, 1969; Stewart, 1970; Snow, 1990).

The Stirling Quartzite is presumed to be Proterozoic Z in age (Stewart, 1970).

\section{Z€w-Wood Canyon Formation}

The Wood Canyon Formation comprises strata that are bounded by the underlying E member of the Stirling Quartzite and the overlying Zabriskie Quartzite (Nolan, 1929). Three informal members of the Wood Canyon Formation, the lower, middle, and upper, were defined for exposures throughout the Death Valley region by Stewart (1970). Subsequently, these informal members were further divided within the southern Grapevine Mountains into six mappable units (Reynolds, 1969). For this report, we will maintain the informal divisions of Stewart (1970).

The total thickness of the Wood Canyon Formation in the Grapevine Mountains is calculated to be $1051 \mathrm{~m}$ in Titanothere Canyon (Reynolds, 1969), but this measurement attempts to account for section cut out across faults and measured at other localities. Similar thicknesses are reported nearby, however, at Bare Mountain (1142 m), at Echo Canyon in the Funeral Mountains (1204 m), and in the Belted Range (1143 m) (Stewart, 1970).

\section{Zwl-Lower Member}

The lower member of the Wood Canyon Formation is composed of four siliciclastic sequences separated at roughly equal intervals by three dolomitic sequences. The lower half of the unit (lower carbonate member of Reynolds, 1969) contains three repetitions of olive-gray to brownish-gray siltstone and quartzite and light-gray dolostone beds, which weather a distinctive orangish-brown. Overlying the carbonate-siltstone repetitions is greenish-gray to brownish-black fine-grained quartzite and siltstone (lower clastic unit of Reynolds, 1969). The quartzites are cross-laminated and locally contain occasional annelid burrows (Reynolds, 1969).

\section{Zwm—Middle Member}

The middle member of the Wood Canyon Formation is a distinctive unit that contains both quartzites and conglomeratic quartzites (conglomeratic quartzite member of Reynolds, 1969; Stewart, 1970). The base of the unit is mapped below a light-gray to white conglomerate bed which contains pebbles as large as 1.5 inches across. The top of the unit is marked by the highest, stratigraphically continuous, conglomeratic quartzite (Reynolds, 1969). The conglomeratic units range from dusky-red to grayish-purple-red and are separated by thin purple to greenish-gray siltstone and phyllitic laminae (Reynolds, 1969; Stewart, 1970; Snow, 1990). An unconformity between the base of the middle member and the lower member is proposed by Reynolds (1969).

\section{ZEwu-Upper Member}

The upper member of the Wood Canyon Formation is lithologically similar to the lower member and consists of siltstone, quartzite, dolostone, and limestone. A concentration of dolostone and limestone in the middle of the upper member led Reynolds (1969) to divide this member into a middle clastic unit, upper carbonate unit, and upper clastic unit.

The upper member of the Wood Canyon Formation contains trilobite debris believed to be earliest Cambrian. Therefore, the 
lower two members of the Wood Canyon Formation are considered to be Proterozoic $\mathrm{Z}$ in age, while the upper member is considered to be Early Cambrian (Stewart, 1970).

\section{€z-Zabriskie Quartzite}

The Zabriskie Quartzite was named for exposures in the Resting Springs Range by Hazzard (1937). The unit is a distinctive thickly to massively bedded quartzite. It ranges in color from grayish-pink to a purplish-red. The unit is cross-bedded and is composed of well-rounded grains. The basal contact is transitional and is mapped where the percentage of quartzite exceeds the percentage of siltstone and thin bedded quartzites of the underlying Wood Canyon Formation.

In the Grapevine Mountains, the Zabriskie Quartzite is 283 311 m thick (Reynolds, 1969). Similar thicknesses have been reported at Bare Mountain (347 m; Cornwall and Kleinhampl, 1964) and in the southern Last Chance Range (416 m; Stewart, 1970).

The age of the Zabriskie Quartzite is Early Cambrian (Stewart, 1970).

\section{$€ c-C a r r a r a$ Formation}

The Carrara Formation was named for exposures at Bare Mountain, to the east of the Grapevine Mountains (Cornwall and Kleinhampl, 1961), and was subdivided further into 9 members (Palmer and Halley, 1979). Strata in the southern Grapevine Mountains, as mapped by Reynolds (1969), are similar to those described by Stewart (1970) in the southern Last Chance Range, where the section is divided into three informal subunits of siltstone and shale, separated by two limestone units, the Gold Ace and Red Pass members. The same basic subdivisions are recognizable in the southern Grapevine Mountains, where Reynolds (1969) mapped three shale members divided by two limestones, called the Girvanella and Red Pass members. In the northern Grapevine Mountains, the Carrara Formation is exposed in a structurally higher thrust plate than in the southern Grapevine Mountains and more closely resembles the formation as mapped at Bare Mountain (Monsen et al., 1992), where two shale units are divided by a single limestone unit. This tripartite division of the Carrara formation yielded the informal member names lower, middle, and upper (Monsen et al., 1992). For the purposes of this report, the threepart division of the Carrara Formation is maintained. Comparisons of strata at Bare Mountain and in the southern Grapevine Mountains indicate that the Girvanella limestone of Reynolds (1969) is equivalent to the middle member of the Carrara Formation of Monsen et al. (1992). In simplifying Reynolds' (1969) mapping for this report, contacts for his Girvanella limestone were retained, but the unit was renamed the middle member of the Carrara Formation. The middle and upper shales, as well as the Red Pass member, of Reynolds' (1969) division of the Carrara Formation were grouped into the upper member of the Carrara Formation.

The thickness of the Carrara Formation in the southern Grapevine Mountains is $465 \mathrm{~m}$ (Reynolds, 1969). At the type locality at Bare Mountain, the unit measures 544 m thick (Cornwall and Kleinhampl, 1961), while sections at Echo Canyon in the Funeral Mountains, and in the southern Last Chance Range measure $384 \mathrm{~m}$ and $501 \mathrm{~m}$ thick, respectively (Hunt and Mabey, 1966; Stewart, 1970).

\section{€cl-Lower Member}

The lower member of the Carrara Formation is transitional from the Zabriskie Quartzite and is mapped where siltstones of the Carrara Formation dominate over quartzite of the Zabriskie Quartzite. These siltstones are predominantly olive-green or olive-gray in color and are platy or phyllitic where deformed. Limestones and calcareous sandstones are interbedded throughout the lower member of the Carrara Formation.

\section{$€ \mathrm{~cm}-$ Middle Member}

The middle member of the Carrara Formation is a prominent, thick, dark gray, massive limestone that is mottled with reddish-orange to orange claystone partings. As mentioned above, this unit was informally called the Girvanella limestone member because of abundant Girvanella algae within the unit (Reynolds, 1969). The limestone is composed largely of carbonate pellets, ooids, and bioclastic debris.

\section{€cu-Upper Member}

The upper member of the Carrara Formation is composed of interbedded siltstone and limestone, as well as thin quartzites and calcareous limestones. The lithology of the siltstones is similar to that of the siltstones in the lower member. Likewise, the lithology of the limestones is similar to that of the middle member of the formation. A prominent limestone with a white top, found approximately halfway through the upper section, is the Red Pass member of Reynolds (1969).

Biostratigraphy indicates that the Carrara Formation ranges in age from Early Cambrian to Middle Cambrian (Reynolds, 1969; Palmer and Halley, 1979). The boundary between Early and Middle Cambrian occurs in the middle of the upper member.

\section{€b-Bonanza King Formation}

The Bonanza King Formation was defined by Hazzard and Mason (1936) and later redefined by Palmer and Hazzard (1956). Two informal subdivisions of the Bonanza King Formation, the lower Papoose Lake Member and the upper Banded Mountain Member, were defined by Barnes and Palmer (1961) for exposures in the Nevada Test Site area. In the Grapevine Mountains, Reynolds (1969) divided the Bonanza King Formation into two units, equivalent to those defined by Barnes and Palmer (1961), but Reynolds does not follow their nomenclature. The Lower Member of Reynolds (1969) is the Papoose Lake Member of Barnes and Palmer (1961), while the Upper Member is equivalent to the Banded Mountain Member. Reynolds further subdivided the Upper Member into striped and banded units. The subdivisions of Reynolds were recognized in the stratigraphy of 
the Bonanza King Formation at Bare Mountain, as were the formal divisions of Barnes and Palmer (1961; Monsen et al., 1992). This report will follow the usage of Monsen et al. (1992) and refer to the lower portion of the Bonanza King Formation as the Papoose Lake Member, while the Banded Mountain Member will be informally divided into lower and upper units (striped and banded units, respectively, of Reynolds, 1969).

In the southern Grapevine Mountains, the Bonanza King Formation is $1097 \mathrm{~m}$ thick (Reynolds, 1969). At Bare Mountain, it is $1158 \mathrm{~m}$ thick (Cornwall and Kleinhampl, 1961), while $1097 \mathrm{~m}$ is reported at Dry Mountain, in the Cottonwood Mountains (Burchfiel, 1969).

\section{€bp_Papoose Lake Member}

The base of the Papoose Lake Member is mapped at the transition from silty limestone and siltstone of the Carrara Formation to medium-gray limestone. This gray limestone comprises only the lowest 60-90 m of the Papoose Lake Member (Snow, 1990). The majority of the Papoose Lake member is massive, mediumto dark-gray dolostone, which is commonly mottled with yellowto yellowish-gray claystone. This member of the Bonanza King Formation is prominent through the Grapevine Mountains, and forms the bulk of the central part of the range.

\section{$€ b b-B a n d e d$ Mountain Member}

The base of the Banded Mountain Member of the Bonanza King Formation is marked by a conspicuous silty dolomite interval. This interval comprises thinly bedded to laminated dolostone, moderate- to light-brown in color (Reynolds, 1969; Snow, 1990). Strata above this unit can be divided further into the upper and lower units of the Banded Mountain Member.

The lower unit is characterized by alternating beds of medium gray to dark gray dolostone, each $0.3-1 \mathrm{~m}$ thick, which give the unit a striped appearance.

The upper unit begins at the base of a prominent bed of thick, massive, dark-gray to black dolostone that overlies the thin bedded dolostones of the lower unit. The unit contains three distinct color bands, a lower dark-gray to black band, a middle light-gray to white band, and an upper brownish-gray to medium-gray band.

The age of the Bonanza King Formation is Middle Cambrian to early Late Cambrian, based on fossils found in the underlying Carrara and overlying Nopah Formations (Hazzard, 1937; Palmer and Hazzard, 1956; Barnes and Palmer, 1961).

\section{€n-Nopah Formation}

The Nopah Formation, named for exposures in the Nopah Range (Hazzard, 1937), is divided into three formal subdivisions - the Dunderburg Member, the Halfpint Member, and the Smokey Member (Christiansen and Barnes, 1966). Reynolds (1969) recognized the Nopah Formation while mapping the southern Grapevine Mountains, but noted only two subdivisions, the shale member (equivalent to the Dunderburg Member) and an upper carbonate member (equivalent to the Halfpint and Smokey members). The contact between the Halfpint and Smokey members is difficult to discern throughout most of the Grapevine Mountains, and so these members are mapped as a single unit in this study.

The thickness of the Nopah Formation in the Grapevine Mountains is $\sim 503 \mathrm{~m}$ (Reynolds, 1969). At the type locality in the Nopah Range, the Nopah Formation measures 530 m thick (Hazzard, 1937). Sections at Bare Mountain and on the Nevada Test Site measure $579 \mathrm{~m}$ and $610 \mathrm{~m}$ thick, respectively (Cornwall and Kleinhampl, 1961; Barnes and Palmer, 1961).

\section{€nd-Dunderburg Member}

The Dunderburg Member of the Nopah Formation is a distinctive olive- to yellow-brown siltstone and shale $\sim 31 \mathrm{~m}$ thick. In outcrop, the unit weathers orangish- to reddish-brown. Several thin limestone horizons occur throughout the Dunderburg Member.

\section{€nu-Upper Member}

The base of the upper member of the Nopah Formation with the Dunderburg Member is gradational, and is mapped where limestone becomes the dominant lithology. Limestone gives way up section to massive light- to dark-gray dolostone. From a distance, the upper member appears as several alternating dark and light bands.

Fossils from the Dunderburg Member of the Nopah Formation are considered to be earliest Late Cambrian in age (Palmer, 1965), while fossils from the upper member of the Nopah Formation are considered to be Late Cambrian in age (McAllister, 1952). Thus, the Nopah Formation is entirely Late Cambrian in age.

\section{Op_Pogonip Group}

The Pogonip Group was defined by Hintze (1951) and further subdivided by Nolan et al. (1956) into the Goodwin Limestone, Ninemile Formation, and Antelope Valley Limestone. This tripartite division has been described in the Death Valley region at Bare Mountain (Cornwall and Kleinhampl, 1961) and at Racetrack Valley in the Cottonwood Mountains (McAllister, 1952; Ross, 1964). The Racetrack Valley section, however, differs from other exposures of the Pogonip Group in the Cottonwood Mountains, and previous workers have defined various subunits within the Pogonip Group in that mountain range (Burchfiel, 1969; Snow, 1990). In the Grapevine Mountains, the subdivisions of Ross (1964) are recognizable and were used as mappable units.

The Pogonip Group is calculated to be $\sim 610 \mathrm{~m}$ thick in the Grapevine Mountains from structure sections, although the only complete section of Pogonip is in the core of the Titus Canyon anticline and may be substantially tectonically thickened. At Bare Mountain, $425 \mathrm{~m}$ are reported by Monsen et al. (1992), similar to the 419 m reported by Cornwall and Kleinhampl (1961). Approximately $427 \mathrm{~m}$ of Pogonip Group are reported for the section at Racetrack Valley in the Cottonwood Mountains (McAllister, 1952; Ross, 1964; Snow, 1990). 


\section{Opg-Goodwin Limestone}

The Goodwin Limestone is a medium- to dark-gray limestone that contains pale orange silt and claystone lenses and chert stringers that weather dark brown. The limestone is thin to thick bedded. The basal contact of the Goodwin Limestone is mapped at the first limestone above the dolostone of the Nopah Formation.

\section{Opn-Ninemile Formation}

The Ninemile Formation comprises light- to medium-brown siltstone and interbedded medium- to dark-gray limestone or dolostone. Limestone and dolostone interbeds are thin, and generally have non-planar "wavy" upper and lower surfaces. The unit can weather various shades of pale red, brownish-orange, or yellowish-orange. The Ninemile Formation is a distinct slope former between the Goodwin Limestone and the Antelope Valley Limestone.

\section{Opa-Antelope Valley Limestone}

The Antelope Valley Limestone is a medium-gray limestone and silty limestone. It is medium- to thick-bedded and contains silt and clay partings that weather a pale orange color. The base of the unit is mapped at the abrupt transition from siltstone of the Ninemile Formation to limestone. Distinctive Maclurites fossils are diagnostic of the Antelope Valley Limestone.

The Pogonip Group is early Early Ordovician to early Middle Ordovician in age (Ross, 1977).

\section{Oe_Eureka Quartzite}

The Eureka Quartzite is recognized throughout the Death Valley region (McAllister, 1952). It was originally named by Hague (1883), but was later redefined by Kirk (1933). The Eureka Quartzite is a medium bedded, locally cross-bedded vitreous quartzite. It is white on fresh surfaces, but may weather shades of rusty red, orange, or brown. The base of the Eureka Quartzite is placed at the lithologic change from silty and sandy dolostones of the underlying Pogonip Group to quartzite. Due to its distinctive lithology, it is a useful marker unit throughout the central and northern Grapevine Mountains.

The Eureka Quartzite measures $116 \mathrm{~m}$ thick in the central Grapevine Mountains. Exposures in the Cottonwood Mountains measure 116-137 m (Burchfiel, 1969; McAllister, 1952; Stadler, 1968; Johnson, 1971). $110 \mathrm{~m}$ of Eureka Quartzite is reported at Bare Mountain (Cornwall and Kleinhampl, 1961).

The Eureka Quartzite is considered to be Middle to early Late Ordovician in age (Cornwall and Kleinhampl, 1961; Ross, 1977).

\section{Oes_Ely Springs Dolomite}

The Ely Springs Dolomite was originally named by Westgate and Knopf (1932) for exposures in northern Nevada. This name was applied to strata in the Nopah Range by Hazzard (1937), and expanded to include strata throughout the Death Val- ley region by McAllister (1952). The Ely Springs Dolomite is composed chiefly of dark gray to black dolostone. The dolostone is fine grained and laminated or thin bedded. Irregularly shaped chert stringers and lenses are common throughout the unit. The base of the Ely Springs Dolomite is mapped at the contact between the underlying white Eureka Quartzite and overlying dark dolostones of the Ely Springs Dolomite.

The Ely Springs Dolomite is $128 \mathrm{~m}$ thick in the Grapevine Mountains. Cornwall and Kleinhampl (1961) report $91 \mathrm{~m}$ of Ely Springs Dolomite at Bare Mountain, while thicknesses in the Cottonwood Mountains vary from 198 to $287 \mathrm{~m}$ (McAllister, 1952; Stadler, 1968; Burchfiel, 1969; Snow, 1990). Variations in thickness of the Ely Springs Dolomite throughout the Death Valley region may be due to an intraformational unconformity (Poole et al., 1977).

The age of the Ely Springs Dolomite is earliest Late Ordovician to Early Silurian (Miller, 1976; Miller and Walch, 1977).

\section{DShv—Hidden Valley Dolomite}

The Hidden Valley Dolomite was named by McAllister (1952) for exposures in the Andy Hills in the Cottonwood Mountains. He also described equivalent rocks from the Funeral Mountains (McAllister, 1974). Snow (1990) divided the Hidden Valley Dolomite into three informal map units within the Cottonwood Mountains, following roughly the lithologic breaks in the unit described by McAllister (1952). No complete section of the Hidden Valley Dolomite is exposed within the Grapevine Mountains, and it is mapped as a single, undivided unit.

The Hidden Valley Dolomite in the Grapevine Mountains consists of a medium-gray cherty dolostone and a higher lightgray, massive, fine grained dolostone. The base of the unit is placed at a cherty horizon above the relatively chert free dolostones of the upper Ely Springs Dolomite. Regionally, the top of the Hidden Valley dolomite is a medium gray dolostone with sandy dolostone lenses that weather a reddish or yellowish orange color. The transition from the light gray massive dolostone that comprises the bulk of the Hidden Valley Dolomite to the sandier top of the unit is not exposed in the Grapevine Mountains.

In the Funeral Mountains, McAllister (1974) reports $439 \mathrm{~m}$ of Hidden Valley Dolomite. A total thickness of $401 \mathrm{~m}$ to $417 \mathrm{~m}$ of Hidden Valley Dolomite is reported from the Cottonwood Mountains (McAllister, 1952; Miller, 1976; Miller, 1978; Snow, 1990), although the thickness of the unit increases from 0 to $\sim 400 \mathrm{~m}$ from southeast to northwest across both the Cottonwood and Funeral Mountains (Snow, 1990).

The age of the Hidden Valley Dolomite ranges from late Early Silurian to late Early Devonian (McAllister, 1974).

\section{Dlb-Lost Burro Formation}

The Lost Burro Formation is a section of siliciclastic and carbonate strata, named for a type section at Lost Burro Gap, in the Cottonwood Mountains (McAllister, 1952). Additional sections 
of the Lost Burro Formation are described by Zenger and Pearson (1969) in the Cottonwood Mountains near the type section, by McAllister (1974) for exposures in the Funeral Mountains, and by Snow (1990) for additional exposures in the Cottonwood Mountains. Originally, the Lost Burro Formation was divided into three units - the lower Lippencott Member, composed dominantly of dolostone, sandy dolostone, and quartzite (McAllister, 1955), a middle unit composed of dolomite, and an upper unit composed of sandstone (Quartz Spring Member of Langenheim and Tischler, 1960). In the Grapevine Mountains, thin slivers of the Lost Burro Formation are present northwest of Mt. Palmer and possibly along the western range front. The strata along the western range front are highly altered by tectonism, making a determination of position within the Lost Burro Formation difficult to ascertain. The Lost Burro Formation is mapped as a single unit in the Grapevine Mountains. Descriptions of the three subunits of the Lost Burro Formation, below, follow from McAllister (1974) and Snow (1990).

The base of the lowermost member of the Lost Burro Formation is mapped at the lowest appearance of chert, quartzite, or sandy worm burrows in a sandy or silty dolostone overlying a yellowish to reddish calcareous shale or argillaceous dolostone (McAllister, 1952, 1974). The unit consists of interbedded sandstone, quartzite, chert, and dolostone. The dolostone changes from light gray to dark gray up section. Two distinctive black bands in the upper part of the unit appear as "railroad tracks" from a distance; the uppermost of these two bands contains Stringocephalus and was designated a marker bed by McAllister (1974).

The middle member of the Lost Burro Formation is dolostone with interbedded limestone. The proportion of limestone increases up section. The unit is medium- to dark-gray. The base of the unit is placed at the basal contact of a black dolostone containing stromatoporoids. This dolostone is $\sim 20 \mathrm{~m}$ above the Stringocephalus marker bed. This unit resembles the Cambrian section, and is distinguished by the presence of stromatoporoids and limestone.

The highest member of the Lost Burro Formation is a light gray limestone. The base of the unit is placed at the color change from dark gray carbonate of the middle member to light gray carbonates of the upper member. Several quartzite beds are located in the upper unit. The top of the upper unit is composed of sandstone and quartzite, which weather brown, and interstratified dolostone. The uppermost part of the Lost Burro Formation resembles the lowermost part, but the presence of Cryptospirifer help differentiate it. The Lost Burro Formation is $610 \mathrm{~m}$ to $684 \mathrm{~m}$ thick in the Cottonwood Mountains (McAllister, 1952; Zenger and Pearson, 1969; Snow, 1990). A thickness of $750 \mathrm{~m}$ is reported in the Funeral Mountains (McAllister, 1974).

The age of the Lost Burro Formation in the Funeral Mountains spans the late Early Devonian to the late Late Devonian (McAllister, 1974). The age of the base of the Lost Burro Formation remains problematical; fossils from the Lippencott Member in the Panamint Mountains yield an early Early Devonian age.
Further work is needed to determine the age equivalence of the base of the Lost Burro Formation in the Death Valley region (for discussion, see Snow, 1990, p. 1:24).

\section{Mrs-Rest Spring Shale (?)}

In contrast to underlying Paleozoic strata, facies changes within the Mississippian section in the Death Valley region are significant, with three major facies belts recognized. From southeast to northwest, these are a limestone shelf facies, a siltstone slope facies, and a siliciclastic basin facies (Pelton, 1966; Dunne et al., 1981; Stevens, 1986). This progression of facies represents a progressive foundering of the continental margin in Mississippian time, leading to a $65 \mathrm{~km}$ eastward migration of the shelfslope break by Pennsylvanian time (Stevens, 1986). Although this marine transgression may be due, in part, to sea level fluctuations, the presence of westerly derived debris flows in deep marine strata of the Inyo Mountains (Stevens, 1986) are indicative of thrust sheet emplacement and tectonic loading of the continental margin during the Antler Orogeny (e.g., Burchfiel and Davis, 1972). Strata of the limestone facies are exposed on the western side of Death Valley in the Cottonwood Mountains, and south of the Grapevine Mountains in the Funeral Mountains (McAllister, 1952; Langenheim and Tischler, 1960; McAllister, 1974; Snow, 1990). Slope facies strata are also exposed in the Cottonwood and Funeral mountains (McAllister, 1952, 1974; Burchfiel, 1969; Snow, 1990). Strata of the siliciclastic basin facies are exposed largely to the north and east of the Grapevine Mountains, at Bare Mountain (Monsen et al., 1992), and throughout the Nevada Test Site (Poole and Sandberg, 1977; Trexler et al., 1996).

Shales and siltstones in the northwestern Grapevine Mountains were assigned to the Rest Spring Shale, part of the siltstone transitional facies (McAllister, 1952; Stevens, 1986), on a reconnaissance map by Reynolds (1969). Equivalent strata in the northern Grapevine Mountains were identified as Mississippian (Albers and Stewart, 1972), but were not correlated to other units outside of the Grapevine Mountains.

These strata consist mainly of siltstones and shales, dark-gray to brown in color, with subordinate dark-gray limestone, granular sandstones and pebble conglomerates. The shales weather olive gray to olive green and are locally pale purple or light-greenish gray in color. Pelmatozoan and brachiopod fragments are reported from conglomerates in the section (Albers and Stewart, 1972), although no positive identification was made of fossil debris collected for this study (J.H. Trexler, 2001, personal commun.).

The siltstones and shales in the northern Grapevine Mountains are highly contorted; at one location an entire cliff face consists solely of stacked anticlinal and synclinal fold axes within a single bed. No reasonable attempt could be made to measure section. Thickness of this unit on the map and cross sections is undoubtedly exaggerated due to stratigraphic duplication.

Trace fossils identified as belonging to the Goniatites granosus zone were collected from the northern Grapevine Mountains (M. Gordon, 1962, reported in Albers and Stewart, 1972). This 
zone is known to be early Late Mississippian in age (early Chesterian). Strata of Mississippian age in the Grapevine Mountains bear no resemblance to any published descriptions of limestone facies strata in the region (McAllister, 1952, 1974; Snow, 1990). Siltstones and shales are common lithologic types in both the siltstone transitional facies, and in the siliciclastic basin facies. Strata in the Grapevine Mountains, however, are unlike any of the well-studied sections of the siliciclastic basin facies (Eleana Formation and Chainman Shale) exposed at Bare Mountain and on the Nevada Test Site (J.H. Trexler, P.H. Cashman, and J.C. Cole, 2000, personal commun.). Lithologically, the Grapevine Mountains section bears closest resemblance to the Rest Spring Shale of the siltstone transitional facies described by McAllister (1952, 1974) and Snow (1990). An early Chesterian age for Mississippian strata in the Grapevine Mountains, however, is significantly younger than the late Chesterian age reported for the base of the Rest Spring Shale in the Cottonwood Mountains (Gordon, 1964). The difference in age between the two sections may indicate that the Rest Spring Shale is time-transgressive, younging toward the (paleogeographic) east with progressive foundering of the continental shelf during the Antler Orogeny, or it may indicate additional complexity in the facies patterns of Mississippian strata in the Death Valley region. Pending further study, the Mississippian strata in the northern Grapevine Mountains are tentatively correlated with the Rest Spring Shale.

\section{CENOZOIC STRATIGRAPHY}

Cenozoic strata are exposed within and around the Grapevine Mountains (Fig. 5). These strata range in age from Oligocene to recent, and fall into three depositional categories: continental clastic sedimentary rocks, ash flow tuffs, and lavas (Fig. 6). Both the oldest and the youngest Cenozoic strata in the Grapevine Mountains fall into the clastic sedimentary depositional category. Late Eocene-Oligocene strata of the Titus Canyon Formation and middle Miocene strata of the Panuga Formation consist of a sequence of fluvial conglomerates and sandstones, as well as sedimentary breccias, presumably landslide deposits, and lacustrine sands, silts, and marls. These strata are easily viewed from Red Pass, looking north up Lost Valley and Titus Canyon, and can be reached by a short hike up the north fork of Titus Canyon, $\sim 1.5 \mathrm{~km}$ west of Leadfield (Fig. 5). Upper Miocene and Pliocene sedimentary deposits of Red Wall Basin are discontinuously exposed along the western front of the Grapevine Mountains, from north of the mouth of Fall Canyon to the Grapevine Ranger Station (Fig. 5). Along the range front, these strata consist of conglomerates, and conglomeratic sandstones, but they grade quickly away from the range front into lacustrine deposits dominated by fine sands, silts, and marls. Recent strata are also sedimentary in nature, and range from alluvial fan systems to playa deposits. Ash flow tuffs in the Grapevine Mountains are exposed along the eastern side of the range (Fig. 5). The tuffs are the products of major volcanic eruptions related to the middle Miocene multi-caldera southwest Nevada volcanic field (e.g., Sawyer et al., 1994). These strata are highly variable in thickness, and consist mainly of moderately densely welded silicic ash flow tuffs. Three lava fields are also identified in the Grapevine Mountains. These range in age from latemiddle Miocene to Pliocene in age, and progress in age from southeast to northwest. These lava fields consist primarily of rhyolitic lavas, silicic non-welded ash flows, and block and ash flows, interbedded with lacustrine sedimentary strata.
Figure 5. Topographic map showing distribution of Cenozoic strata.

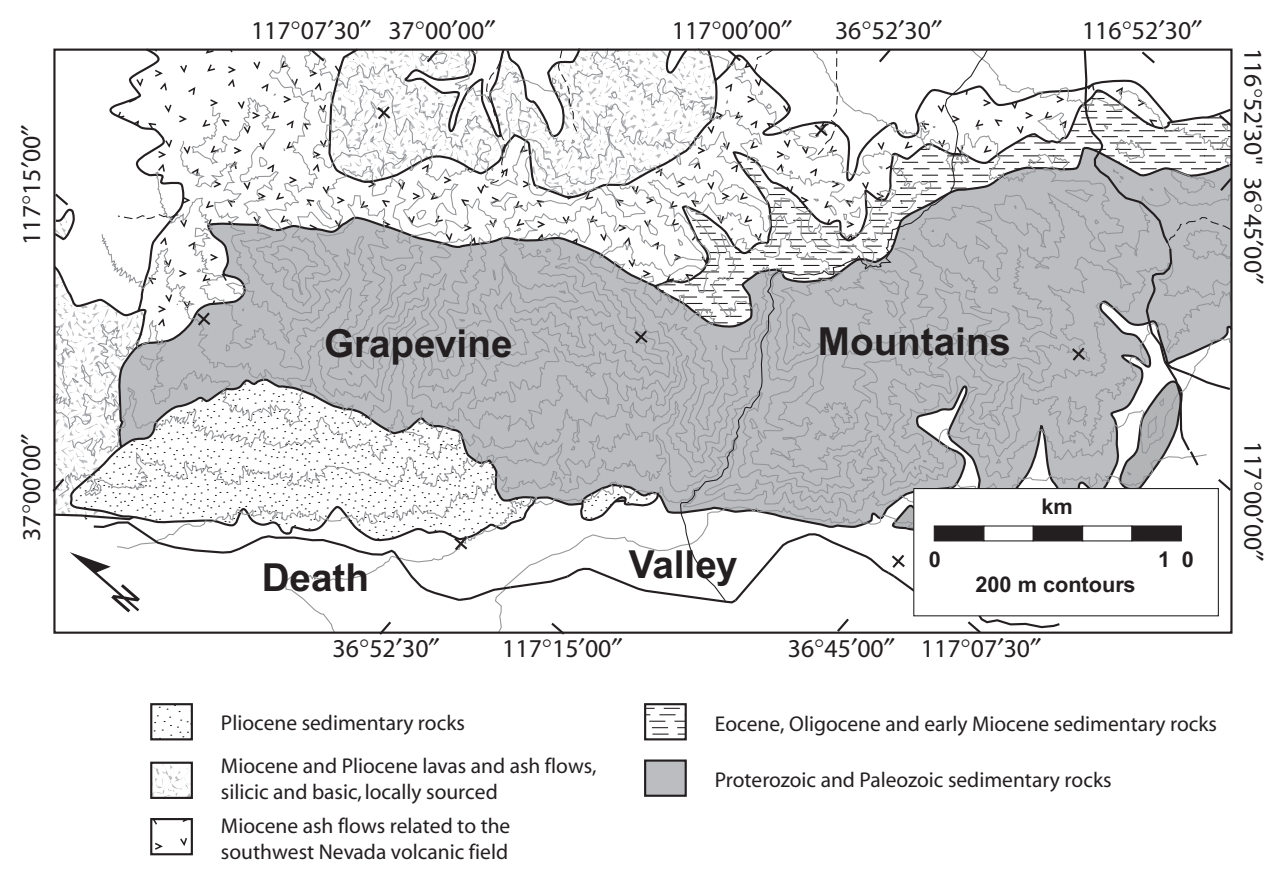




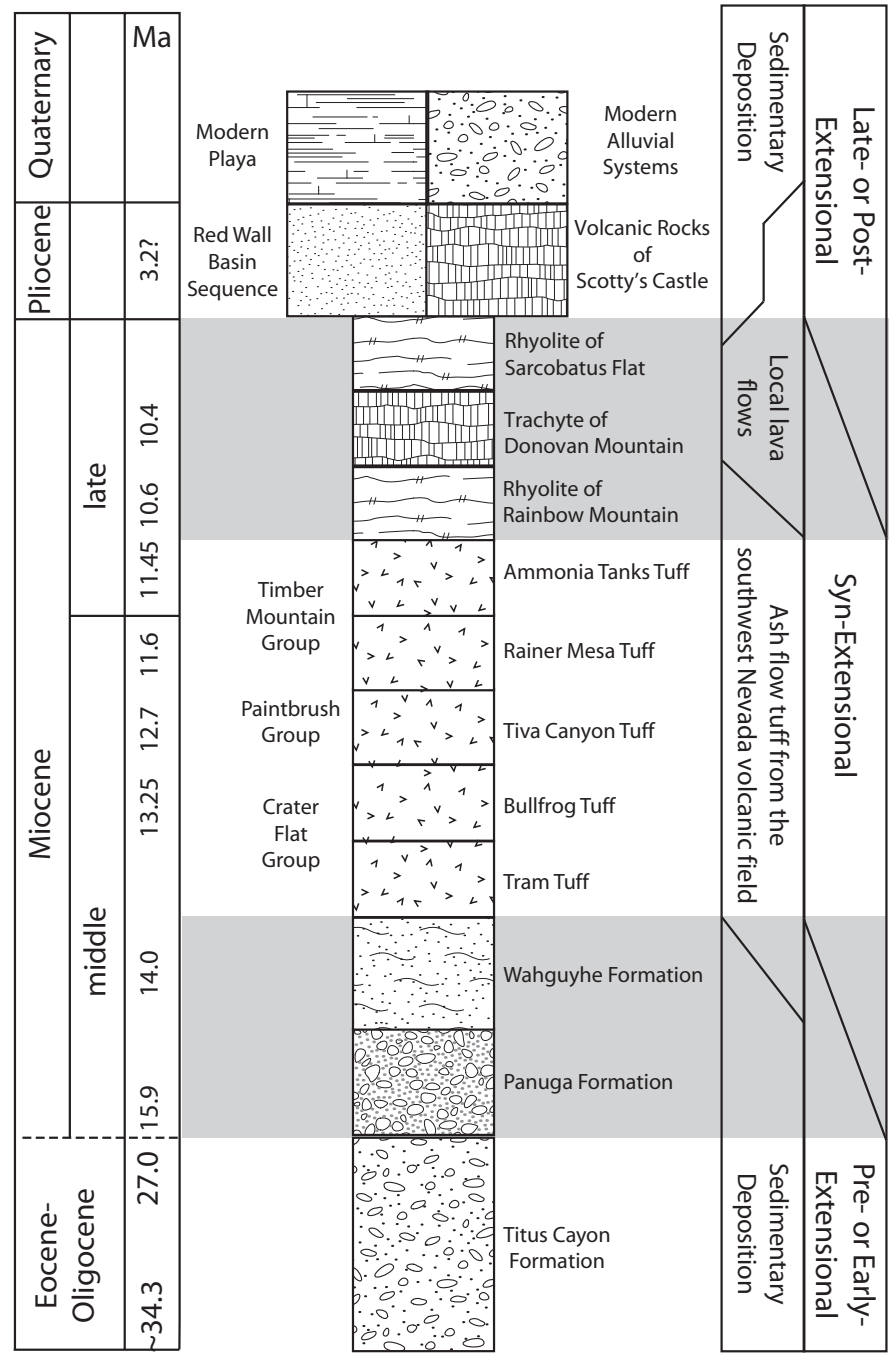

Figure 6. Composite columnar section of Cenozoic strata in the Grapevine Mountains.

As detailed below, this report describes ash flow tuffs in the Grapevine Mountains, correlative with units from the southwest Nevada volcanic field, which have not previously been identified in this area. Additionally, some modifications in nomenclature of the middle Miocene sedimentary sequence are proposed. A summary of this information, along with previous Cenozoic stratigraphy identified in the Grapevine Mountains, is shown in Figure 7. Map units of the Southwest Nevada volcanic field ash flow tuffs are shown in Figure 8.

\section{EOGtc-Titus Canyon Formation}

The name Titus Canyon Formation was originally applied to a sequence of sedimentary strata in upper Titanothere Canyon, in the southern Grapevine Mountains (Stock and Bode, 1935). Detailed stratigraphic descriptions of the formation, sedimentary analysis, and measured sections were reported by Reynolds
(1969) and Saylor (1991). Four lithologic facies were named by Reynolds (1969) for sections in the Titus Canyon region: the lower sedimentary breccia facies, the variegated facies, the brown conglomerate facies, and the green conglomerate facies. An unconformity between the green conglomerate facies and underlying variegated facies led Reynolds (1969) to postulate that the green conglomerate facies may be substantially younger than the lower three facies of the Titus Canyon Formation. Geochronologic work on tuffs within the upper green conglomerate yielded ${ }^{40} \mathrm{Ar} /{ }^{39} \mathrm{Ar}$ ages of $12.0 \mathrm{Ma}$ (Saylor and Hodges, 1994) and 15.9 Ma (Snow and Lux, 1999). The presence of the unconformity between the green conglomerate and lower Titus Canyon Formation, as well as isotopic ages within the green conglomerate that were substantially younger than the Chadronian age reported for the lower Titus Canyon Formation, discussed below (Stock and Bode, 1935; Reynolds, 1974; Saylor and Hodges, 1994), led to a revision of the Titus Canyon Formation nomenclature (Snow and Lux, 1999). Under this revised stratigraphy, the three lower facies of the Titus Canyon Formation maintain the name Titus Canyon Formation. The green conglomerate facies is reassigned to the Panuga Formation (Snow and Lux, 1999). Below are summarized the stratigraphic descriptions (Reynolds, 1969) of the three facies of the revised Titus Canyon Formation.

Sedimentary Breccia Facies. The sedimentary breccia facies occurs at the base of the Titus Canyon Formation. The breccia is heterolithic, and contains angular, locally derived clasts of Paleozoic strata, as well as some well-rounded pebbles and cobbles of quartzite. The proportion of well-rounded quartzite clasts increases as the breccia grades into the variegated facies. The breccia is bedded, and has a matrix composed of calcareous siltstone, pale red or yellow in color. Sandstone interbeds are also present in some localities. The proportions of siltstone and sandstone in the breccia facies decreases southward.

Variegated Facies. The variegated facies was named for the numerous colors the unit displays in outcrop around the town of Leadfield, predominantly yellows, reds, and greens in the lower portion of the facies, with reds in the upper part. Rock types exposed in the variegated facies range from pebble and cobble conglomerates to calcareous siltstones, mudstones, and marls to fine-grained sandstones. The sandstones are lithic and quartz arenites with clasts of quartzite, carbonate, and chert. The conglomerates contain well-rounded pebbles and cobbles. Many cobbles are fractured and re-healed. The clasts are composed of carbonate, chert, quartzite, and occasional granitic rocks. Conglomerates in the variegated facies are commonly lenticular, and grade into sandstones; rarely do the conglomerates interfinger with siltstone or mudstone.

Brown Conglomerate Facies. The brown conglomerate facies is composed of yellowish-brown or grayish-orange weathering, well-rounded pebble and cobble conglomerate. Subangular blocks of underlying Paleozoic carbonate rocks, as well as older Titus Canyon marls, are also deposited in the brown conglomerate facies. Coarse-grained sandstone and pebbly sandstone lenses are found throughout the conglomerate, as are some marl beds. 

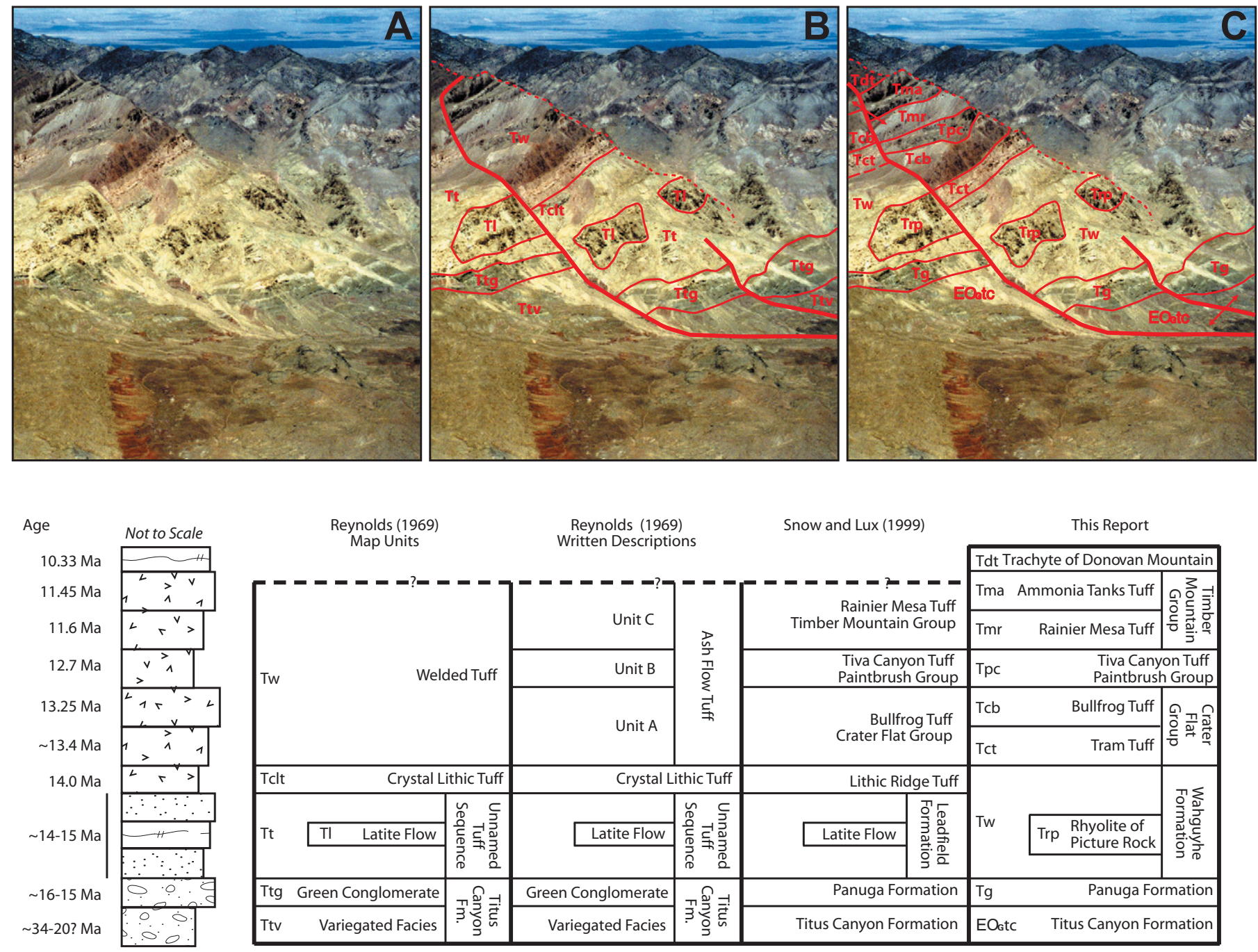

Figure 7. Photographs and chart showing changes in Tertiary stratigraphy of the Grapevine Mountains suggested by this report. (A) Photograph looking north into Titus Canyon, showing a fairly complete Eocene/Oligocene to middle Miocene stratigraphic sequence. (B) Overlain on the photograph is the Tertiary stratigraphy mapped by Reynolds (1969). (C) Overlain on the photograph is the Tertiary stratigraphy recognized in this report. Units shown include subdivisions that are not mapped as individual map units on Plate 1. The chart underneath the photographs shows the evolution of stratigraphic nomenclature in the Grapevine Mountains.

The thickness of the Titus Canyon Formation varies across the study area. At the type section, in Titus Canyon, $640 \mathrm{~m}$ is preserved (Reynolds, 1969). However, as much as $914 \mathrm{~m}$ is present in the northern Funeral Mountains (Cornwall and Kleinhampl, 1964), while as little as $213 \mathrm{~m}$ is preserved north of Grapevine Peak (Stock and Bode, 1935).

The age of the lower part of the Titus Canyon Formation was established as Chadronian (Late Eocene or Early Oligocene) on the basis of vertebrate fossils (Stock and Bode, 1935). An isotopic age, of unspecified type, of $27 \mathrm{Ma}$ is reported for a tuff bed near the middle of the Titus Canyon Formation (Reynolds, 1974). Two tuff beds in the lower Titus Canyon Formation yielded ${ }^{40} \mathrm{Ar} /{ }^{39} \mathrm{Ar}$ ages of 30.0 and $34.3 \mathrm{Ma}$ (Saylor and Hodges, 1994).

\section{Tg-Panuga Formation}

The Panuga Formation was defined by Snow and Lux (1999) for exposures in the Cottonwood Mountains, described as a "heterogeneous succession of conglomerate, pebbly lithic wacke, and siltstone." Distinguishing features of the Panuga Formation are the presence of intraclasts from the underlying Titus Canyon Formation, granitic and volcanic clasts, tuff beds, and tuffaceous sandstones. The Panuga Formation is defined as the sequence of strata overlying the first major unconformity within the Tertiary sedimentary sequence. On the basis of similarities between the type Panuga Formation and the green conglomerate facies of the Titus Canyon Formation, the green conglomerate facies was reassigned to the Panuga Formation (Snow and Lux, 1999). Sum- 

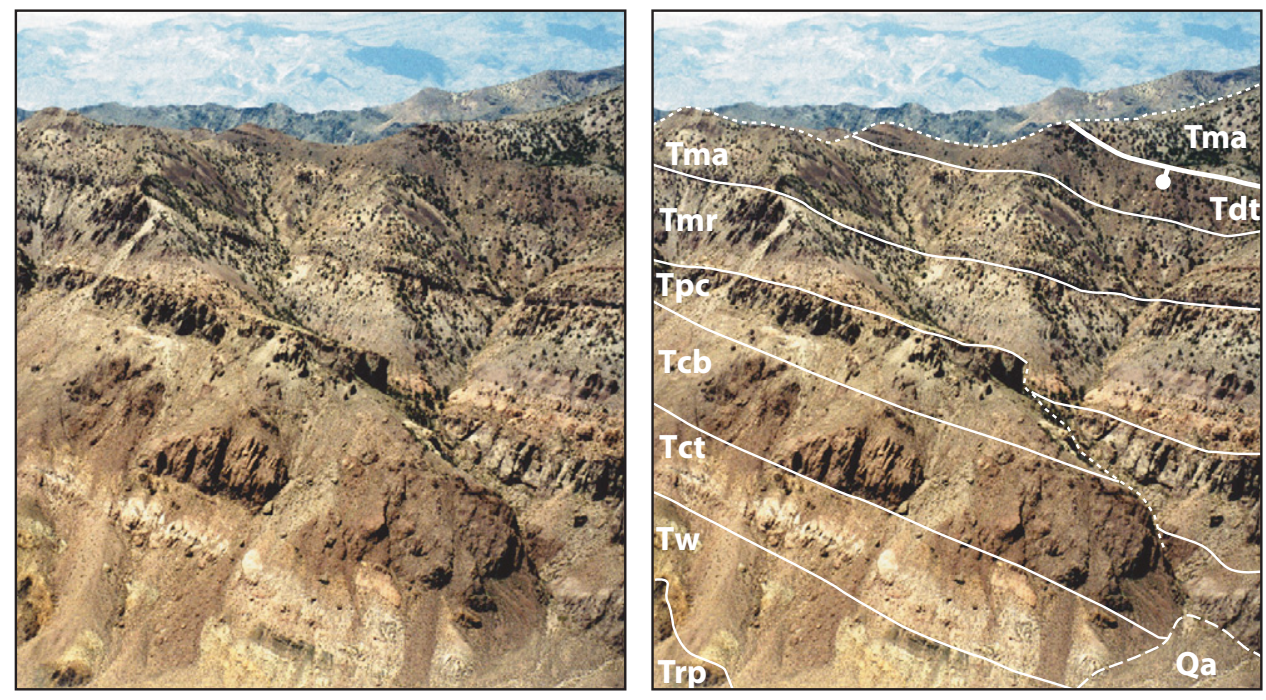

Crater Flat Group

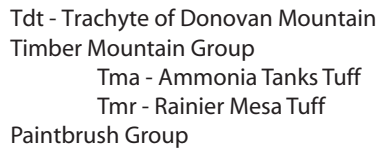

marized below is the stratigraphy of the Panuga Formation in the Grapevine Mountains, as described from the type section of the green conglomerate facies (Reynolds, 1969).

The Panuga Formation unconformably overlies the variegated facies of the Titus Canyon Formation. It contains greenishgray, pale-green, or grayish-brown weathering conglomerate beds, up to $1.2 \mathrm{~m}$ thick, that are interbedded with fine- to coarse-grained sandstone and pebbly sandstone. Clasts in the conglomerate are generally well rounded, and are as large as cobble-sized, although large, $0.9 \mathrm{~m}$ subangular limestone blocks are locally present. The clasts are Paleozoic clastic and carbonate rocks, granites, and silicic volcanics. Sandstones and conglomerates in the green conglomerate facies are commonly tuffaceous.

A tuff within the Panuga Formation in the Grapevine Mountains has been correlated with the regionally extensive Tuff of Unconformity Hill (15.9 Ma; Snow and Lux, 1999), while tuffs in the upper part of this unit are tentatively correlated with Crater Flat tuffs (ca. 13.5 Ma) from the Southwest Nevada volcanic field (C. Fridrich, 2001, personal commun.). Thus, the Panuga Formation is early middle Miocene in age.

\section{Tw-Wahguyhe Formation}

The Wahguyhe Formation was originally described by Reynolds (1969), who called the unit the "Unnamed Tuff Sequence." On the basis of its stratigraphic position, the name Leadfield Formation was assigned to this sequence of strata in the Grapevine Mountains and Bullfrog Hills (Snow and Lux, 1999). This name, unfortunately, is problematic, since an ash
Figure 8. (A) Photograph of ash flow tuffs of the southwest Nevada volcanic field exposed on the western wall of Titus Canyon. (B) Contacts between ash flow tuff units recognized in this study, overlain on the same photograph. Subdivisions of units are shown that are not mapped on Plate 1. Short dashed lines are ridge lines. Strata beyond upper ridge line are Paleozoic strata. flow tuff exposed in the same geographic region had previously been assigned the name "Tuff of Leadfield Road" (Maldonado, 1990a, 1990b). Since the term "Tuff of Leadfield Road" is a lithostratigraphic designation with established usage, a change in nomenclature for the Leadfield Formation may be appropriate. The Leadfield Formation of Snow and Lux (1999) crops out in and near the Wahguyhe Peak quadrangle (USGS 7.5' quad). Since (1) stratigraphic sequences in the Death Valley region identified by Snow and Lux (1999) are named primarily using Native American terminology, (2) Wahguyhe is a Native American term, and (3) the word Wahguyhe has no previously established stratigraphic usage, I propose that the Leadfield Formation be renamed the Wahguyhe Formation.

The Wahguyhe Formation is a sequence of sedimentary and volcanic units. Sedimentary rocks include sandstone, porcelaneous shale, and minor conglomerate. These strata weather yellowish-gray to yellowish-brown, and may have dark spots on a weathered surface. Sandstones and shales are tuffaceous, and fine-grained. Volcanic units consist of silicic tuffs and a latite lava flow. The tuffs are usually white, but may weather shades of yellow or buff, and are highly altered with resorbed phenocrysts. The latite lava flow is correlated with the Rhyolite of Picture Rock (Slate et al., 1999) on the basis of stratigraphic position and lithologic similarity. The latite lava flow weathers dark brown and contains phenocrysts of oligoclase, andesine, biotite, hornblende, and augite set in a matrix of plagioclase (Reynolds, 1969).

The thickness of the Wahguyhe Formation varies through the Titus Canyon region, where it is best exposed, from 488 to $853 \mathrm{~m}$ (Reynolds, 1969). The percentage of sedimentary and volcanic rocks in this sequence is also locally variable, and rocks of 
correlative age are primarily of volcanic origin in the southernmost Grapevine Mountains (Fridrich and Thompson, 2011).

Correlation of the latite flow with the Rhyolite of Picture Rock suggests an age for this flow of 14.0 Ma (Slate et al., 1999). Thus, the Wahguyhe Formation is early middle Miocene in age.

\section{Tc_Crater Flat Group}

In the southern Grapevine Mountains, three ash flow tuffs have been recognized (Reynolds, 1969). These three tuffs were originally named, from lowest to highest, A, B, and C. Reynolds (1969) described the tuffs, and proposed the correlation of each tuff with a recognized unit within the Nevada Test Site. The oldest of the tuffs in the Grapevine Mountains, Ash Flow Tuff A, was tentatively correlated with the "Tuffs of Crater Flat" (as described by Christiansen and Lipman, 1965). The "Tuffs of Crater Flat" were formally redefined by Sawyer et al. (1994) as the Crater Flat Group, which is composed of three tuffs: from oldest to youngest, the Tram Tuff, the Bullfrog Tuff, and the Prow Pass Tuff. Paleomagnetic studies support correlation of Ash Flow Tuff A with the Crater Flat Group (Snow et al., 1993; Hudson et al., 1994). In the original description of Ash Flow Tuff A, Reynolds (1969) described a single cooling unit, leading Snow and Lux (1999) to correlate Ash Flow Tuff A with the Bullfrog Tuff of the Crater Flat Group. Subsequent work has identified two cooling units, the Tram Tuff and the Bullfrog Tuff of the Crater Flat Group, in the Grapevine Mountains (C.J. Fridrich, unpublished mapping). Detailed descriptions of the Crater Flat Group are reported by Carr et al. (1986); units present in the Grapevine Mountains are summarized below.

Tram Tuff. The Tram Tuff of the Crater Flat Group is present in the Grapevine Mountains as a pale red pumiceous tuff. Lithic fragments are more common in the lower portion of the tuff, where they are composed of some Paleozoic fragments, but chiefly of rhyolite and intermediate composition lavas. The upper part of the unit is relatively free of lithics. Phenocrysts of quartz, sanidine, and biotite are present within the Tram Tuff. Quartz phenocrysts in the Tram Tuff are generally not resorbed, in contrast to the strongly resorbed quartz found in the overlying Bullfrog Tuff. The top of the Tram Tuff is marked, at some locations, by an altered white tuffaceous siltstone, or by the transition from the non-welded or weakly welded Tram Tuff to the basal vitrophyre and strongly welded Bullfrog Tuff.

Bullfrog Tuff. The Bullfrog Tuff of the Crater Flat Group overlies the Tram Tuff throughout the Grapevine Mountains. The base of the Bullfrog Tuff is marked by a dark gray or black vitrophyre, overlain by a brick-red to brownish-red welded tuff. Pumice fragments in the welded zone are flattened to fiamme, defining a prominent foliation. The welded unit grades upward into a partially welded zone, which weathers gray or pinkish-gray. Phenocrysts in the Bullfrog Tuff comprise as much as $20 \%$ of the welded zone, but decrease to $\sim 10 \%$ in the partially welded zone. Phenocrysts are predominantly quartz, sanidine, and plagioclase, but biotite is also present in small amounts.
The thickness of the combined Crater Flat Group in the Grapevine Mountains is $\sim 91 \mathrm{~m}$.

The age of the Bullfrog Tuff is $13.25 \mathrm{Ma}\left({ }^{40} \mathrm{Ar} /{ }^{39} \mathrm{Ar}\right.$ on sanidine; Sawyer et al., 1994). The age of the Tram Tuff is not known through geochronologic means, but is constrained to be between 13.25 Ma, the age of the overlying Bullfrog Tuff, and 13.5 Ma, the age of the Dead Horse Flat Formation of the Belted Range Group, which underlies the Tram Tuff on the Nevada Test Site (Sawyer et al., 1994).

\section{Tp-Paintbrush Group}

Strata of the Paintbrush Group were originally described by Hinrichs and Orkild (1961), Orkild (1965), Poole and McKeown (1962) and Lipman and Christiansen (1964). The name Paintbrush Tuff was originally applied to these strata by Orkild (1965). Four members of the Paintbrush Tuff were reported by Christiansen and Lipman (1965); however, redefinition of the strata and its members was codified by Byers et al. (1976b). Of the four members of the Paintbrush Group, the distribution of the three lowest members is known to be restricted to the east of the Grapevine Mountains (Lipman and Christiansen, 1964; Lipman et al., 1966a). Correlation of Ash Flow Tuff B with the highest member of the Paintbrush Group, the Tiva Canyon Member, was proposed by Reynolds (1969), and endorsed by Snow and Lux (1999). Revision of volcano-stratigraphic nomenclature in the Nevada Test Site area led to a change in nomenclature from the Paintbrush Tuff to the Paintbrush Group, and from the Tiva Canyon Member to the Tiva Canyon Tuff, but with no attendant changes in lithologic definitions (Sawyer et al., 1994). Detailed descriptions of the Paintbrush Group are reported in Byers et al. (1976b), and summarized below, along with descriptions specific to the Grapevine Mountains (Reynolds, 1969).

Tiva Canyon Tuff. The Tiva Canyon Tuff of the Paintbrush Group is a single cooling unit comprised of devitrified, welded tuff. It is gray to reddish-brown in color, and partially welded or non-welded at its top and base. At its type section, the Tiva Canyon Tuff is divided into three compositional zones; the lowest is crystal-poor biotite- and sanidine-rhyolitic tuff, the middle is crystal-poor biotite-bearing tuff, and the upper is a crystal-rich quartz-latitic tuff. Only the two lower, crystal-poor compositional zones are present in the Grapevine Mountains. Large lithophysal and gas cavities are a distinguishing field characteristic of the Tiva Canyon Tuff.

The Tiva Canyon Tuff is as thick as $274 \mathrm{~m}$ in the Grapevine Mountains just east of Leadfield (Reynolds, 1969).

The age of the Tiva Canyon Tuff is reported as $12.7 \mathrm{Ma}$ $\left({ }^{40} \mathrm{Ar} /{ }^{39} \mathrm{Ar}\right.$ on sanidine; Sawyer et al., 1994).

\section{Tm-Timber Mountain Group}

The name Timber Mountain Tuff was originally assigned to volcanic strata in the vicinity of Timber Mountain by Orkild (1965). This definition included strata previously described by 
Lipman et al. (1966b), Carr and Quinlivan (1966) and Byers et al. (1976a). The Timber Mountain Tuff was redefined (Byers et al., 1976a) to comprise four members. Two of these are exposed only within the Timber Mountain caldera, but two others, the lower Rainier Mesa Member and upper Ammonia Tanks Member, are distributed throughout the Nevada Test Site region. The names "Rainier Mesa member" and "Ammonia Tanks member" of the "Timber Mountain Tuff" were changed to "Rainier Mesa Tuff" and "Ammonia Tanks Tuff" of the "Timber Mountain Group" by Sawyer et al. (1994). Reynolds (1969) correlated Ash Flow Unit C in the Grapevine Mountains with the Rainier Mesa Tuff of the Timber Mountain Group, a correlation endorsed by Snow and Lux (1999); however, both the Rainier Mesa Tuff and the Ammonia Tanks Tuff are present in the Grapevine Mountains. Summarized below are descriptions of the Rainier Mesa Tuff and Ammonia Tanks Tuff, as described by Byers et al. (1976b).

Rainier Mesa Tuff. The Rainier Mesa Tuff is a single cooling unit that is moderate brown, pale red, or light gray in color. A partially welded zone at the base gives way upward to a densely welded zone. Phenocrysts comprise $20 \%$ of the Rainier Mesa Tuff, with quartz being the most abundant, but also including sanidine, plagioclase, and biotite. The Rainier Mesa Tuff is distinguished, in part, from the Ammonia Tanks Tuff because it lacks sphene phenocrysts. Phenocrysts of quartz can be $\sim 1 \mathrm{~mm}$ across; the size of the quartz phenocrysts, a gray welded as opposed to dark red welded zone, and a lack of fiamme distinguish the Rainier Mesa Tuff from the Bullfrog Tuff of the Crater Flat Group. In many exposures throughout the Nevada Test Site area, including nearby exposures in the Bullfrog Hills (Cornwall and Kleinhampl, 1964; Maldonado, 1990b; Maldonado and Hausback, 1990), a thin basalt flow separates the Rainier Mesa Tuff from the Ammonia Tanks Tuff. This basalt, however, is generally absent in the Grapevine Mountains, and the contact between the Rainier Mesa Tuff and the Ammonia Tanks Tuff is placed at the upper boundary of the welded zone of the Rainier Mesa Tuff, although it is locally marked by the presence of a thin basalt flow (C. Fridrich, unpublished mapping).

Ammonia Tanks Tuff. The Ammonia Tanks Tuff is an ash flow tuff composed, in the Grapevine Mountains, of a single cooling unit. Despite the fact that the Ammonia Tanks Tuff is "compositionally far more complex than the Rainer Mesa Member [sic]" (Byers et al., 1976b, p. 46), in hand sample they are nearly impossible to distinguish. The presence of basalt lithic fragments within the Ammonia Tanks Tuff and the occurrence of chatoyant sanidine are the primary methods of differentiating the two members of the Timber Mountain Group in the field. The presence of sphene is also indicative of the Ammonia Tanks Tuff, although this is rarely observable in hand sample.

The thickness of the Timber Mountain Group, calculated from structure sections, is $\sim 488 \mathrm{~m}$ in Titus Canyon; however, the unit thickens northward toward Wahguyhe and Grapevine peaks. There, it appears to exceed $1 \mathrm{~km}$ in thickness, although exposure is too poor to rule out repetition of the section by faulting.
The age of the Rainier Mesa Tuff is $11.6 \mathrm{Ma}$; the age of the Ammonia Tanks Tuff is $11.45 \mathrm{Ma}\left({ }^{40} \mathrm{Ar} /{ }^{39} \mathrm{Ar}\right.$ on sanidine; Sawyer et al., 1994).

\section{Trr-Rhyolite of Rainbow Mountain}

The name Rhyolite of Rainbow Mountain was first used to describe a series of silicic volcanic strata in the Bullfrog Hills (Eng et al., 1996). Portions of this sequence were previously identified as "tuffs and lavas of the Bullfrog Hills" (Noble et al., 1991) and by Maldonado (1990a, 1990b) and Maldonado and Hausback, (1990). A revision of the Rhyolite of Rainbow Mountain as defined by Eng et al. (1996) is provided by Connors et al. (1998). The Rhyolite of Rainbow Mountain is found on the eastern edge of the Grapevine Mountains (Maldonado and Hausback, 1990), although strata identified as Rhyolite of Rainbow Mountain in the northwestern corner of their map are now known to be associated with a lithologically similar, but younger, sequence, the Rhyolite of Sarcobatus Flat (described below; C.J. Fridrich, unpublished mapping).

The Rhyolite of Rainbow Mountain comprises rhyolite lava flows, rhyolitic ash flow tuffs, block and ash flows, and debris flows comprised mainly of volcaniclastic materials. Ash flow tuffs are predominantly non-welded or partially welded and are white to pale buff or pale pink in color. Lavas are reddish-brown to grayish-blue in color, and are commonly rich in phenocrysts. No lithologic descriptions or measurements of these units were made for this study. Locally, the Rhyolite of Rainbow Mountain interfingers with basalts overlying the Timber Mountain tuff, and these units are mapped together. For a detailed description of the Rhyolite of Rainbow Mountain see Connors et al. (1998, p. 6-8) and Fridrich and Thompson (2011).

The thickness of the Rhyolite of Rainbow Mountain varies from 0 to $600 \mathrm{~m}$ in the Bullfrog Hills (Maldonado, 1990a). The Rhyolite of Rainbow Mountain was erupted over an $\sim 1$ m.y. period, from 11.3 to $10.5 \mathrm{Ma}$ (Fridrich and Thompson, 2011).

\section{Tdt-Trachyte of Donovan Mountain}

The name "latite of Donovan Mountain" was first used by Minor et al. (1993) to describe lava flows at Donovan Mountain, near Beatty, Nevada. The usage was extended to include other lava flows of similar age (younger than the Timber Mountain Group) in the Nevada Test Site region (Minor et al., 1993). Lava flows included in this expanded definition include those mapped in the Bullfrog Hills (Ransome et al., 1910; Cornwall and Kleinhampl, 1964; Maldonado and Hausback, 1990). In the Grapevine Mountains, trachyte lava flows overlie the Ammonia Tanks Tuff of the Timber Mountain Group, and locally overlie the Rhyolite of Rainbow Mountain, along the crest of the range, west of Titus Canyon, and south of Grapevine Peak. This report assigns trachyte lava flows overlying Timber Mountain Group tuffs in the Grapevine Mountains to the Trachyte of Donovan Mountain (Fridrich and Thompson, 2011). 
The Trachyte of Donovan Mountain is composed of flows and breccias of dark-gray to reddish brown trachyte lava. Phenocrysts account for 5\%-20\% of the rock, and are predominantly plagioclase, sanidine, and biotite, with hornblende, clinopyroxene, and olivine. The matrix is devitrified. Chemical analyses of the trachyte are reported by Cornwall and Kleinhampl (1964).

The thickness of the Trachyte of Donovan Mountain ranges from 0 to $425 \mathrm{~m}$ in the Bullfrog Hills (Connors et al., 1998), but at no place in the Grapevine Mountains are both basal and upper contacts exposed.

The best estimate of the age of the Trachyte of Donovan Mountain is 10.33 Ma from exposures in the Bullfrog Mountains (Eng et al., 1996, ${ }^{40} \mathrm{Ar} /{ }^{39} \mathrm{Ar}$ on alkali feldspar). The Trachyte of Donovan Mountain in the Grapevine Mountains is assumed to be of a similar age.

\section{Trs-Rhyolite of Sarcobatus Flat}

The term Rhyolite of Sarcobatus Flat is an informal name applied to a sequence of silicic lavas and tuffs located near Sarcobatus Flat, which lies to the east of the Grapevine Mountains (Slate et al., 1999; Fridrich and Thompson, 2011). This sequence was first mapped as Tertiary rhyolites, but no distinction was made between it and other rhyolites in the region (Cornwall, 1972). Rocks of this sequence were mapped as part of the Rhyolite of Rainbow Mountain in the northwestern Bullfrog Hills (Maldonado and Hausback, 1990), but subsequent work indicated the need for two separate successions on the basis of field relations and geochronologic data (C.J. Fridrich, unpublished mapping; Fridrich and Thompson, 2011).

The Rhyolite of Sarcobatus Flat consists of a complex series of rhyolite lava flows, plugs, and domes, block and ash flows, airfall tuffs, and possibly shallow intrusions (Fig. 9A). The lavas range in color from reddish-brown to grayish-green, range from crystal rich to crystal poor, and are commonly flow-banded. Ashfalls and block and ash flows consist of rhyolitic tuff, usually white or buff in color, and may contain lithic fragments of rhyolite or basalt; in the case of the block and ash flows, blocks may be greater than $50 \mathrm{~cm}$ across (Fig. 9B). A detailed description of this rhyolite field was beyond the scope of this study; to the best of the author's knowledge, no such description has been published, although geochronologic age constraints on this unit are presented by Fridrich and Thompson (2011). Excellent exposures of lavas of the Rhyolite of Sarcobatus Flat may be observed along the Strozzi Ranch Road, west of where it intersects the Phinney Canyon Road, to the end of the road at Brier Spring (Fig. 1). Well-exposed block and ash flows are accessible by foot by hiking west from the end of the Strozzi Ranch Road along the north wall of the canyon.

The thickness of the sequence is likely variable across the width of exposure, and nowhere within the study area is the top of the sequence clearly exposed. The nature of these deposits yield bedding that dips as much as $60^{\circ}$; however, a substantial portion of this dip could be depositional. Additionally, structural mapping within the sequence was not attempted, so duplication of section due to faulting is a distinct possibility. Nonetheless, a thickness of $914 \mathrm{~m}$ can be conservatively estimated in the vicinity of Brier Spring and Phinney Canyon.

$\mathrm{An}{ }^{40} \mathrm{Ar} /{ }^{39} \mathrm{Ar}$ age of $9.9 \mathrm{Ma}$ is reported for units low in the Rhyolite of Sarcobatus Flat, while the Spearhead Tuff (7.5 Ma) overlies the Rhyolite of Sarcobatus Flat, making the sequence early Late Miocene in age (Fridrich and Thompson, 2011).

\section{Tvs_-Volcanic Rocks of Scotty's Castle}

The term Volcanic Rocks of Scotty's Castle is informally applied to a series of silicic and basic volcanic rocks in the vicinity of Scotty's Castle, in northern Death Valley National Park. No detailed description of the sequence has been made for this report, nor is the existence of one known. Rocks of this sequence were originally mapped as Tertiary volcanic rocks, undivided (Strand, 1967). Silicic rocks in the sequence are lithologically similar to the Rhyolite of Sarcobatus Flat; however, rocks in this sequence unconformably overlie the Rhyolite of Sarcobatus Flat in the northeastern Grapevine Mountains (C.J. Fridrich, unpublished mapping). The presence of basalt flows within the sequence also distinguishes it from the Rhyolite of Sarcobatus Flat. Exposures of the silicic volcanic succession are easily accessed within the vicinity of Scotty's Castle and throughout Grapevine Canyon. Basalt flows of the Volcanic Rocks of Scotty's Castle are less accessible, in general; however, one excellent exposure in Bonnie Claire flat lies just south of Nevada Route 267, east of the upper end of Grapevine Canyon.

The exact ages of the Volcanic Rocks of Scotty's Castle are unknown. Three K-Ar analyses on whole rock basalt from the northern Grapevine Mountains (north of Scotty's Castle) yield ages from 1.7 to $3.6 \mathrm{Ma}$ (M. Reheis, unpublished data). A tuff within the sequence has been tentatively correlated with the Tuff of Mesquite Spring (3.2 Ma; Snow and White, 1990) during reconnaissance mapping (C.J. Fridrich, 2011, personal commun.). Until further study is undertaken, the Volcanic Rocks of Scotty's Castle are assumed to be middle to late Pliocene in age.

\section{Trw_Red Wall Basin Sequence}

The term Red Wall Basin sequence is informally applied to a sequence of sedimentary strata exposed along the western flank of the Grapevine Mountains, from north of the mouth of Fall Canyon to the Grapevine Ranger Station (Plate 1; Fig. 5). The best exposures of the sequence are just north of the mouth of Red Wall Canyon, which gives the sequence its name.

Strata of the Red Wall Basin consist of two sedimentary sequences separated by a mild angular unconformity. The lower sequence consists of fine sandstones, siltstones, and marls, presumably deposited in a lacustrine environment, interspersed with beds of alluvial and fluvial conglomerate that become more predominant to the north. The sandstones are buff to light yellow in color, though where carbonate-rich, they may weather 

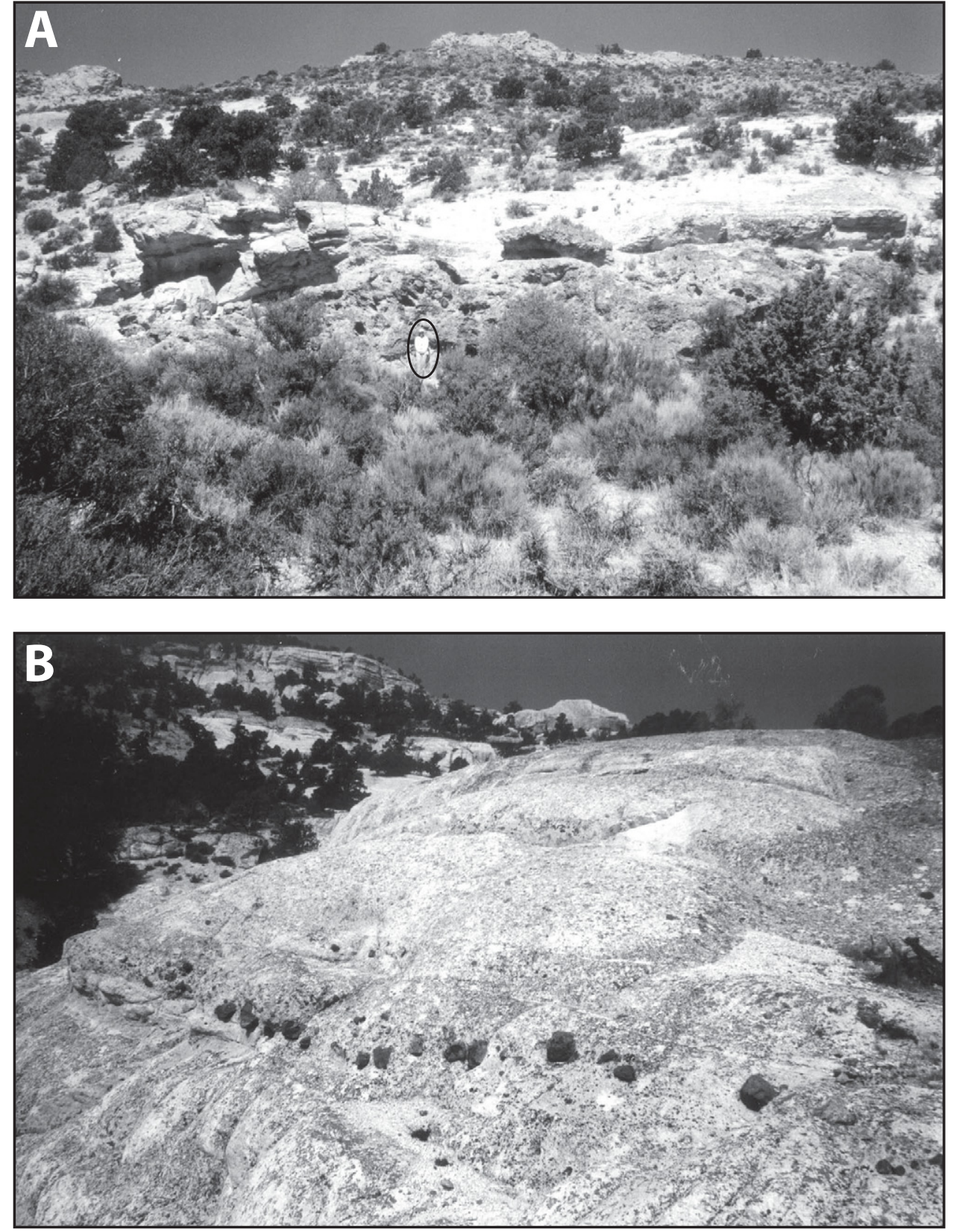

Figure 9. (A) Photographs of the Rhyolite of Sarcobatus Flat overlain by ash flow tuffs east of Brier Spring. Lava flows are dark gray and blocky in appearance, and crop out near the base of the cliff face. Note person in center of photo for scale. (B) Ash flows of the Rhyolite of Sarcobatus Flat north of Brier Spring. Note string of large clasts across center of photo. Clasts are $20 \mathrm{~cm}$ in diameter. a yellowish-orange (Fig. 10). Interspersed conglomerate beds are generally medium- to dark-brown in color and consist of clasts of Paleozoic carbonate, welded tuff, and silicic lava. These strata interfinger with coarse conglomerates near the Grapevine Mountains range front. The coarse conglomerates consist mainly of clasts of Paleozoic carbonate strata and weather brick-red or reddish-brown. The facies change between the alluvial conglomerates and lacustrine facies occurs over a distance of $\sim 100 \mathrm{~m}$. Within the lower exposures of the lacustrine facies strata is at least one basalt flow. The basalt weathers dark-gray to black but is internally medium-gray. The flow contains phenocrysts of olivine, usually altered, and pyroxene.
Overlying the above sequence in mild angular unconformity is a sequence of alluvial conglomerates. These conglomerates contain clasts mainly derived from the Paleozoic section, usually no larger than cobble-sized. The conglomerates weather tan to medium brown. Within these conglomerates are an unwelded ash flow tuff and several ash-fall tuffs. These tuffs are buff or dirty white on weathered surfaces and bright white on fresh surfaces. The tuffs are friable and poorly lithified, and are composed largely of pumice lapilli with phenocrysts of biotite and sanidine.

Exposures of the Red Wall Basin deposits along the western margin of the Grapevine Mountains are insufficient to determine the thickness of either the upper or the lower sequence. 
Figure 10. Photograph looking north along the western range front of the Grapevine Mountains, 1 mile north of Fall Canyon. Yellow and orange colored beds on the left side of the photo are deposits of the Red Wall Basin sequence. Person in left center of photo for scale.

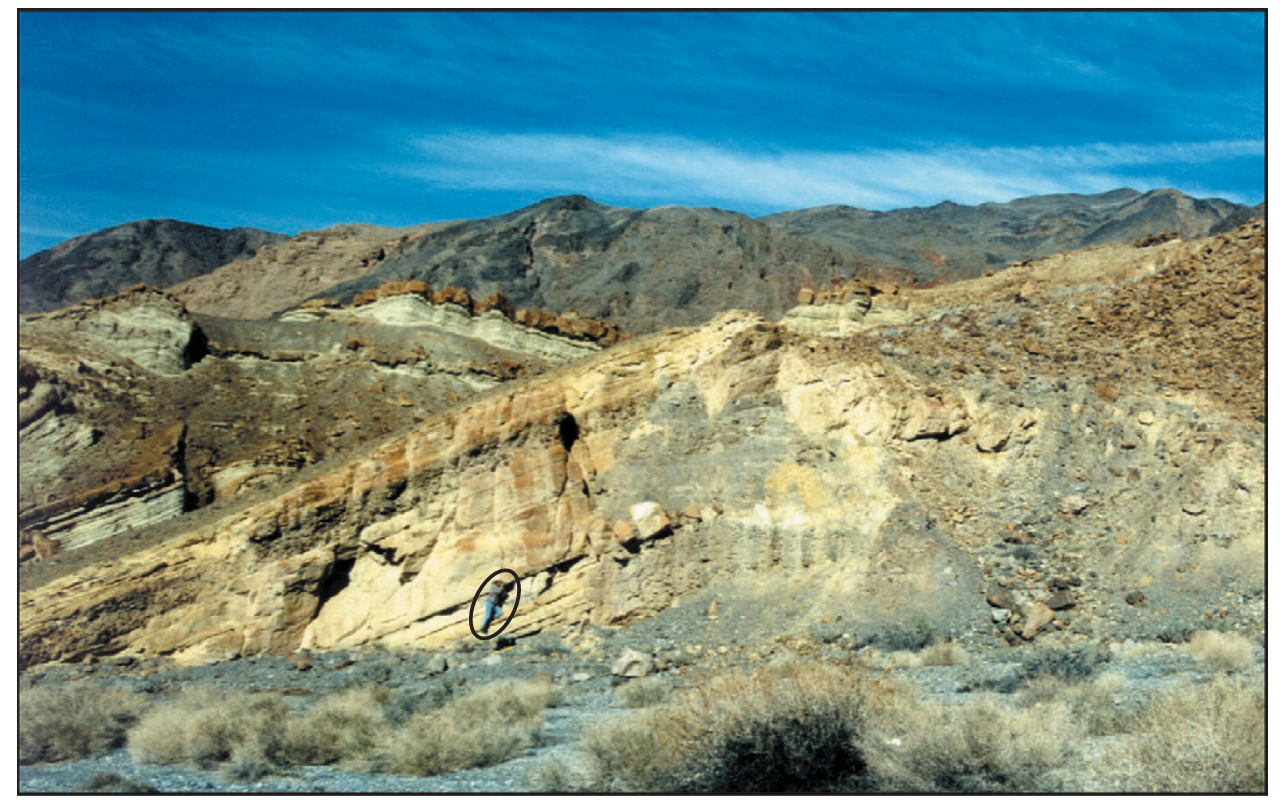

The age of the Red Wall Basin deposits is unknown. A tuff within the upper sequence yields (U-Th)/He zircon ages of $3.09 \pm 0.19 \mathrm{Ma}$ (Table 1), suggesting a tentative correlation with the 3.2 Ma Tuff of Mesquite Spring (Snow, 1990; Snow and Lux, 1999). Presumably, the Red Wall Basin deposits are early- to mid-Pliocene in age, and would be correlative with the Nova Formation found on the western side of Death Valley (Snow and Lux, 1999).

\section{QTg-Quaternary Gravels}

Outcrops of poorly to moderately consolidated conglomerates located within the Grapevine Mountains are mapped as Quaternary gravels. These gravels weather grayish-brown to reddish-brown, and contain clasts of locally derived Paleozoic carbonate and Tertiary volcanic rocks. Although not well lithified, they are distinguished from older alluvium on the basis of location (often capping hills and ridges), moderate induration, and sandy matrix. The age of these gravels is unknown. Lithologic similarities between these gravels and the upper sequence of the Red Wall Basin deposits suggest that they may be equivalent in age, making them Pliocene. In Red Wall Canyon, one exposure of gravels weathers reddish-brown, is strongly lithified, and may be significantly older than Quaternary in age. Mapped outcrops of QTg in Red Wall may locally contain both older and younger sediments.

\section{QTIs-Quaternary Landslides}

Landslide deposits of indeterminate age are present within the Grapevine Mountains, particularly in the Titus Canyon region, where the slides appear to localize along friable ash flow tuff horizons. A spectacular landslide is exposed on the east wall of Fall Canyon, opposite the peak of Mt. Palmer. Smaller slides are found in the Titanothere Canyon area, while some older slides, potentially coeval with emplacement of the ash flow sheets, are located on the eastern wall of Titus Canyon (C.J. Fridrich, unpublished mapping).

\section{Quaternary Alluvium}

Weakly lithified to unlithified gravels and sands within canyons of the Grapevine Mountains, and along the range front, are mapped as Quaternary alluvium. These deposits were separated into five units on the basis of lithification, stratigraphic position,

TABLE 1. (U-Th)/He GEOCHRONOLOGY OF ZIRCONS FROM RED WALL BASIN TUFF

\begin{tabular}{lcccrrr}
\hline \hline Sample $^{\dagger}$ & $\mathrm{F}_{\mathrm{t}}$ & $\begin{array}{c}\mathrm{U} \\
(\mathrm{ppm})\end{array}$ & $\begin{array}{c}\text { Th } \\
(\mathrm{ppm})\end{array}$ & $\begin{array}{c}{ }^{4} \mathrm{He} \\
(\mathrm{ncc} / \mathrm{mg})\end{array}$ & $\begin{array}{c}\text { Raw age } \\
(\mathrm{Ma})\end{array}$ & $\begin{array}{c}\text { Corrected age }^{\ddagger} \\
(\mathrm{Ma})\end{array}$ \\
\hline NAN-MST-RWBa & 0.74 & 561.73 & 312.74 & 187.66 & $2.43 \pm 0.03$ & $3.26 \pm 0.04$ \\
NAN-MST-RWBc & 0.79 & 331.18 & 211.37 & 112.68 & $2.43 \pm 0.03$ & $3.06 \pm 0.03$ \\
NAN-MST-RWBd & 0.82 & 239.01 & 193.14 & 80.49 & $2.23 \pm 0.03$ & $2.84 \pm 0.03$ \\
NAN-MST-RWBe & 0.72 & 396.20 & 221.60 & 125.60 & $2.30 \pm 0.03$ & $3.19 \pm 0.04$ \\
Mean Age & & & & & & $\mathbf{3 . 0 9} \pm \mathbf{0 . 1 9}$ \\
\hline
\end{tabular}

'Sample locality at $36^{\circ} 53^{\prime} 01^{\prime \prime} \mathrm{N}, 117^{\circ} 13^{\prime} 28^{\prime \prime} \mathrm{W}\left(\sim 3 \mathrm{~km}\right.$ NNW of the mouth of Red Wall Canyon, Grapevine Peak $7.5^{\prime}$ quadrangle).

${ }^{\ddagger}$ Ages determined on single zircon crystals. Single crystals were hand-picked from a zircon separate created from crushate using standard density and magnetic techniques. Ages corrected for alpha-ejection after Farley (2000). 
and degree of pavement and desert varnish development. All of these units contain angular to well-rounded clasts, as large as boulder-sized, derived from the local area around the exposure. Predominantly, this means that the clasts are composed of Paleozoic carbonate, although in the southern Grapevine Mountains, siliciclastic clasts from the lower miogeocline should dominate. Extremely well-rounded clasts are usually recycled from the Titus Canyon Formation and may show evidence of fracturing and rehealing. Clasts of Tertiary sedimentary and volcanic rocks are also prevalent, particularly in upper Titus and Fall canyons.

\section{Qoa-Older Alluvium}

Gravels that are weakly indurated, have a strong desert varnish development, and are located within the mountain range, usually high on walls of canyons or old alluvial terraces, are mapped as older alluvium. These deposits generally have strongly developed desert varnish, and may have an unlithified matrix of fine sand or silt. Where these gravels were deposited against the side of a canyon, both varnish and matrix may locally be absent. Gravels assigned to older alluvium are exposed only internally to the range. The ages of these deposits probably range from Pleistocene to Recent (Hunt and Mabey, 1966; Reynolds, 1969).

\section{Q4-Alluvium Q4}

Gravels assigned to the Q4 level are the oldest gravels exposed along the range front. The surface formed by these gravels is being incised by present day processes, yet, where preserved, the surface usually forms a topographic high on the modern fan. The Q4 surface is easily recognized for its well-developed desert pavement and heavy desert varnish. Underneath the desert pavement layer is a layer of fine silt. Alluvium Q4 gravels are thought to be Pleistocene in age (Hunt and Mabey, 1966).

\section{Q3-Alluvium Q3}

Weakly indurated gravels with a modestly developed desert pavement and medium to light desert varnish are assigned to alluvium Q3. Surfaces formed on alluvium Q3 usually stand above younger alluvial surfaces. In some places, alluvium Q3 is indurated enough to support terraces $\sim 25 \mathrm{~m}$ high. The age of alluvium Q3 is late Pleistocene to Recent (Reynolds, 1969).

\section{Q2-Alluvium Q2}

Gravels that stand above the modern active wash are mapped as alluvium Q2. Alluvium Q2 gravels are poorly to un-indurated and have a light coat of desert varnish or no coat at all. Desert pavement is not developed on alluvium Q2 surfaces; instead the alluvium Q2 surfaces are rilled and dissected. Alluvium Q2 is Recent in age.

\section{Qa-Alluvium Qa}

Unconsolidated gravels and sands in the bottom of canyons and active alluvial washes are assigned to alluvium Qa. No desert varnish or desert pavements are observed in alluvium Qa. Alluvium Qa surfaces are uneven and rough. The age of alluvium Qa is Recent.

\section{STRUCTURAL GEOLOGY}

The geologic structures of the Grapevine Mountains can be subdivided into two categories: contractional structures related to the development of the Cordilleran fold and thrust belt in Late Paleozoic and Mesozoic time, and Basin and Range extensional structures related to the late Cenozoic fragmentation of the Cordilleran thrust belt. Although extension between range blocks of the Basin and Range may be extreme, many blocks, such as the Grapevine Mountains, are internally little extended, thus allowing a straightforward interpretation of the Late Paleozoic and Mesozoic geologic structures within the range.

\section{Contractional Structures}

Three major contractional structures related to the Cordilleran thrust belt are identified within the Grapevine Mountains. From structurally lowest to highest position they are the Titus Canyon anticline, the Bonnie Claire thrust system, and the Grapevine thrust. Based on correlations with similar structures in other nearby ranges (Snow and Wernicke, 1989, 2000; Snow, 1992), these are the structurally highest elements of the Death Valley thrust belt, the oldest portion of the Cordilleran thrust belt exposed in the western United States, and were active from middle Permian to middle Triassic time (Dunne, 1986; Stevens and Stone, 1988; Snow et al., 1991; Stevens and Stone, 2002, 2005a, 2005b).

\section{Titus Canyon Anticline-Corkscrew Peak Syncline}

The Titus Canyon anticline-Corkscrew Peak syncline fold pair was named by Reynolds (1969) for exposures of a large amplitude $(>1 \mathrm{~km})$ west-vergent anticline-syncline pair located in the southern Grapevine Mountains. The synclinal member of the fold pair, the Corkscrew Peak syncline, is exposed mainly in the southern Grapevine Mountains, south of Plate 1; however, it reappears northward along the range front in the footwall of the Moonlight Canyon fault (Sections B-B' and $\mathrm{C}-\mathrm{C}^{\prime}$, Plate 1; see discussion of Grapevine thrust, below). The Titus Canyon anticline is best exposed on the northern wall of Titus Canyon (Fig. 11), although the fold continues northward through the central portion of the Grapevine Mountains, where the overturned limb of the fold is again well exposed to the northwest of Mt. Palmer (Fig. 12; Plate 1), before the fold rapidly dies out along strike.

In the Titus Canyon area, the fold is recumbent, with the axial surface dipping $\sim 15^{\circ}$ to the east (Section D-D'; Reynolds, 1969). The fold becomes upright to slightly overturned north of Titus and Fall canyons (Sections B- $\mathrm{B}^{\prime}$ and $\mathrm{C}-\mathrm{C}^{\prime}$, Plate 1), and the axial surface dips moderately eastward. The Titus Canyon anticline involves strata as old as the Upper Proterozoic Wood Canyon Formation and as young as the Mississippian Rest Spring Shale. The fold is dissected by east-dipping Cenozoic normal faults, which place the upright limb of the fold against the overturned limb in at least two locations (Sections B- $\mathrm{B}^{\prime}$ and 
Figure 11. The Titus Canyon anticline looking north, on the northern wall of Titus Canyon. Unit abbreviations as on Plate 1. Dotted lines are ridge lines.
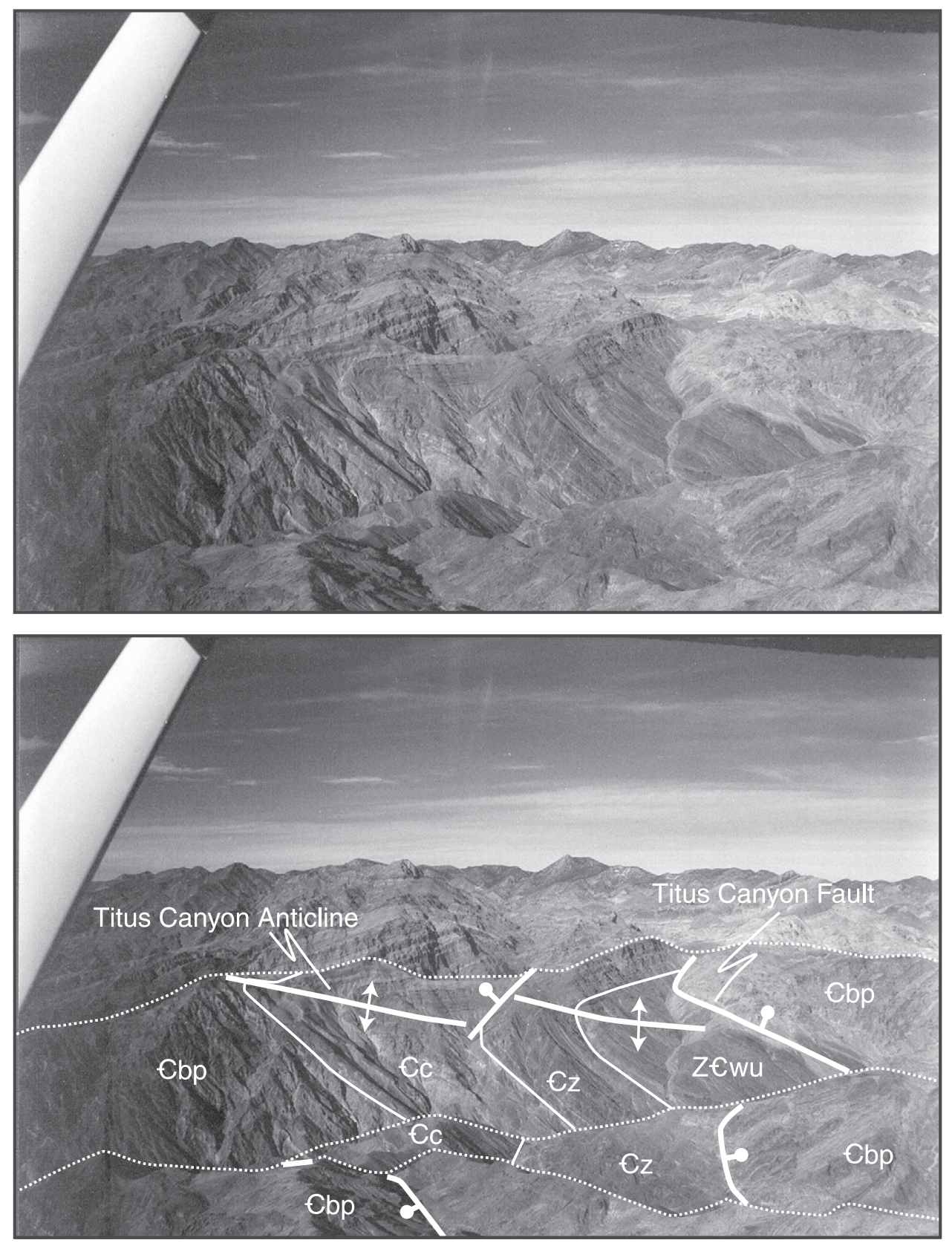

$\mathrm{C}-\mathrm{C}^{\prime}$, Plate 1). Total shortening across the Titus Canyon anticline is difficult to constrain given the exposures in the Grapevine Mountains, but is minimally $2 \mathrm{~km}$.

\section{Bonnie Claire Thrust System}

A single thrust fault, the northern continuation of the large, east-vergent, Grapevine thrust (discussed below), was originally mapped throughout the northern Grapevine Mountains (Reynolds, 1969, 1974). Snow (1992) recognized that the thrust of Reynolds could not be contiguous with the Grapevine thrust, and renamed it the "Intermediate thrust." Snow (1992) hypothesized that this thrust was correlative with the Racetrack duplex zone exposed in the Cottonwood Mountains, which lies between presumed correlatives of the Titus Canyon anticline and the Grapevine thrust. Detailed mapping indicates that the single east-vergent thrust of Reynolds (1969; 1974) and Snow (1992) is actually a series of west-vergent thrust sheets of moderate displacement (Section A-A', Plate 1). These thrusts are here named the Bonnie Claire thrust system (Plate 1) for the Bonnie Claire Dry Lake to the northeast of the exposures. The westernmost of the Bonnie Claire thrusts is the most substantial, and places strata as old as middle Cambrian over Mississippian Rest Spring Shale. The upper plate of this thrust is internally imbricated, yielding several repetitions of the Ordovician section, and local younger-over- 

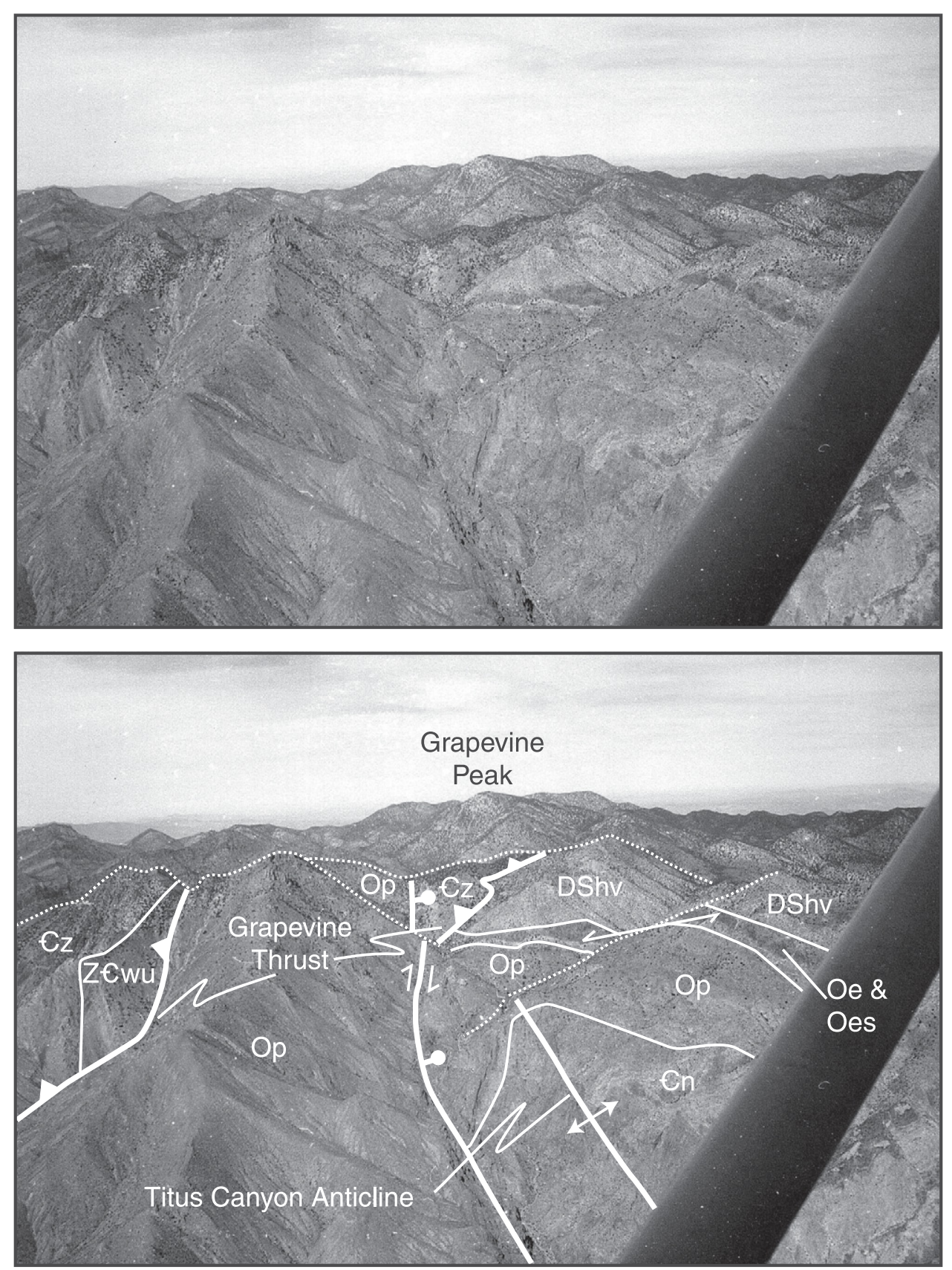

Figure 12. The Titus Canyon anticline looking north, $\sim 2 \mathrm{~km}$ northwest of Mt. Palmer. Note both the overturning of the Grapevine thrust, and its repetition across normal faults. Unit abbreviations as on Plate 1. Dotted lines are ridge lines. older thrust relationships (Fig. 13; Plate 1). The complex internal geometry of the Bonnie Claire thrust system is best displayed on the northern wall of Moonlight Canyon (Plate 1), which provides a natural cross section through the thrust stack. The Bonnie Claire thrust system is truncated to the east by an east-dipping normal fault that places the hanging wall of the structurally higher Grapevine thrust down against the Bonnie Claire system.

The largest throw in the Bonnie Claire thrust system is Middle Cambrian Bonanza King Formation over Mississippian Rest Spring Shale, yielding a stratigraphic throw of $\sim 2.5 \mathrm{~km}$. Both the fact that the Bonnie Claire thrust system accommo- dates roughly the same amount of shortening as the Titus Canyon anticline, and that the fact that Bonnie Claire thrust system dies southward at about the same latitude that the Titus Canyon anticline dies northward (Plate 1), suggests that the Bonnie Claire thrust system accommodates west-vergent deformation that is absorbed southward along strike by the Titus Canyon anticline.

\section{Grapevine Thrust}

The Grapevine thrust is a major east-vergent thrust fault that was originally mapped through the central portion of the Grapevine Mountains by Reynolds (1969, 1974; Sections B-B' and 
Figure 13. The Bonnie Claire thrust system. View looking south toward Backthrust Canyon. Note thrust duplication of Ordovician section. Unit abbreviations as on Plate 1. Dotted lines are ridge lines.
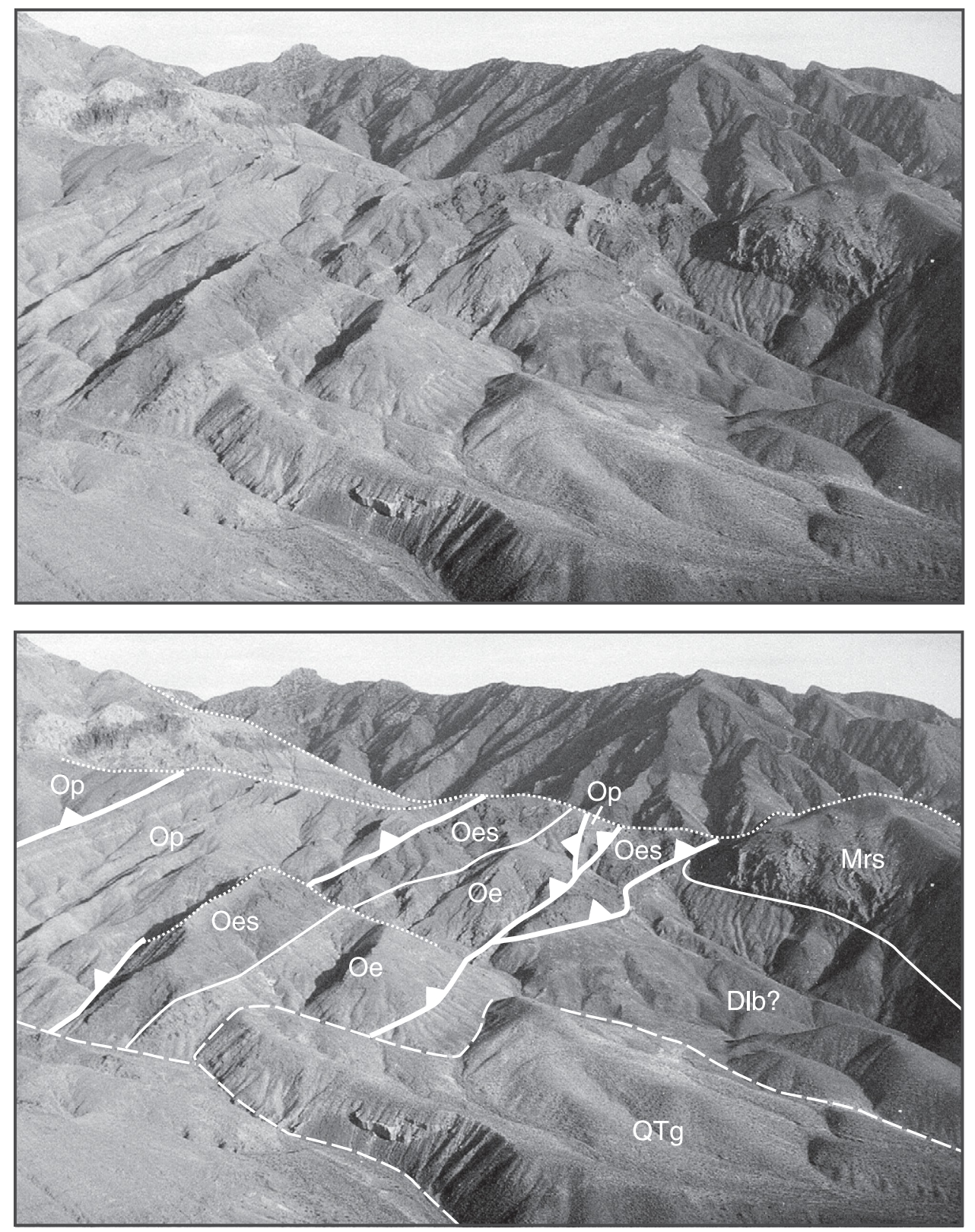

$\mathrm{C}-\mathrm{C}^{\prime}$, Plate 1). The westernmost exposure of the thrust occurs in the footwall of the Moonlight Canyon fault (Plate 1), where the Upper Proterozoic E Member of the Stirling Quartzite and the Wood Canyon Formation are thrust over Mississippian Rest Spring Shale and Devonian Lost Burro (?) Formation. The geologic relations here are complex, as the thrust appears to have undergone two generations of folding after it formed. The first generation involves folding the thrust into a west-vergent syncline, most likely related to west-vergent folding associated with the Titus Canyon fold system (Sections B-B' and $\mathrm{C}-\mathrm{C}^{\prime}$, Plate 1). A later deformation event re-folded the thrust about an east-westtrending axis. The folded thrust is truncated by the Moonlight Canyon fault, but reappears in the hanging wall of the Moon- light Canyon fault at a structurally higher position in the westvergent fold (Sections B-B' and C-C', Plate 1). Here the Grapevine thrust places the Lower Cambrian Zabriskie Quartzite and Carrara Formation over Upper through Middle Ordovician strata of the Ely Springs Formation, Eureka Quartzite, and Pogonip Group (Plate 1; Fig. 14). The attitude of the thrust changes from mildly to steeply west dipping as it is folded into the overturned limb of the fold pair, suggesting that the thrust is deformed by the fold (Sections B-B' and C-C', Plate 1). The structural level of the thrust in the core of the fold has been erosionally removed; however, another normal fault repeats the Grapevine thrust on the northern flank of Mt. Palmer (Plate 1). At this locality, the Grapevine thrust carries Zabriskie Quartzite and Carrara Forma- 

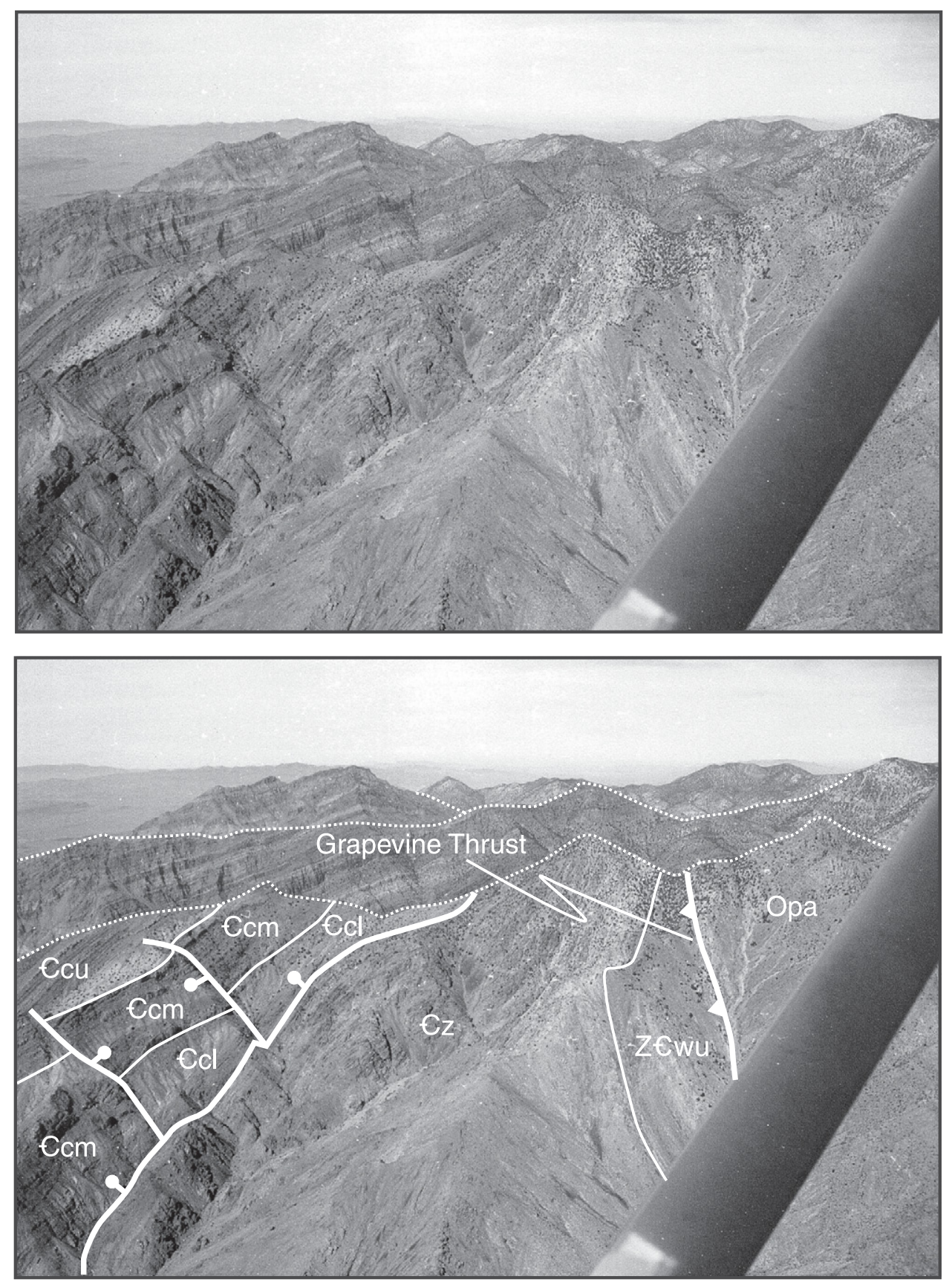

Figure 14. The Grapevine thrust in the central Grapevine Mountains, looking north toward Grapevine Peak. Note overturning of Grapevine thrust along the overturned limb of the Titus Canyon anticline. Area in this figure is in the left center of Figure 12. Unit abbreviations as on Plate 1. Dotted lines are ridge lines. tion strata over the Devonian Lost Burro Formation and Hidden Valley Dolomite (Section C-C', Plate 1).

The greatest stratigraphic throw on the Grapevine thrust is Upper Proterozoic strata over Mississippian strata, $\sim 5 \mathrm{~km}$, in the footwall of the Moonlight Canyon fault. The Grapevine thrust in the hanging wall of the Moonlight Canyon fault places Lower Cambrian strata over Ordovician, for a stratigraphic throw of $\sim 2.5 \mathrm{~km}$, while the easternmost exposure of the Grapevine thrust places Lower Cambrian strata over Devonian, for a throw of $\sim 3.5 \mathrm{~km}$. These observations are difficult to reconcile with a simple thrust ramp model. The Grapevine thrust apparently cuts both up and down section in the hanging wall in the direction of transport, and stratigraphic throw both decreases and increases in the transport direction. The observation that stratigraphic throw decreases toward the core of the Titus Canyon anticline, and that the Grapevine thrust cuts down section into the core of the anticline, and up section out of the core of the anticline, suggests that the Grapevine thrust cut through a previously deformed section, beheading an antecedent Titus Canyon anticline. Later motion on the Titus Canyon fold pair folded the Grapevine thrust, resulting in the complex structural relations currently observed. 


\section{Extensional Structures}

Normal faults in the Grapevine Mountains are related to regional late Cenozoic extensional tectonism throughout the Basin and Range province. Extension began as early as early Eocene time, as recorded by sedimentary deposits in the southern Grapevine Mountains (Stock and Bode, 1935), and continues to the present. The Grapevine Mountains appear to contain several generations of extensional structures, as discussed below.

\section{Moonlight Canyon Fault}

The Moonlight Canyon fault and related structures are likely the oldest set of extensional faults in the Grapevine Mountains. These structures are named for their spectacular exposure in Moonlight Canyon (Fig. 15, Plate 1). The Moonlight Canyon fault is an east-dipping normal fault that disrupts the west-vergent Titus Canyon anticline and places the upright, anticlinal portion of the Titus Canyon fold against the overturned Corkscrew Peak syncline in the footwall of the fault (Plate 1). Related faults include a west-dipping normal fault that runs to the east of Mt. Palmer (Plate 1), and an east-dipping fault that runs in the canyon west of Mt. Palmer (Plate 1). Although no geologic relations exist that indicate that the latter two faults were active synchronously with the Moonlight Canyon fault, all three faults share several commonalities. First, they are internal to the range, not along the range front. Second, they dip in toward the center of the range, not out toward the edges. Third, these faults have no present topographic signature. Together, these observations suggest that this group of faults is not currently active and that they likely pre-date formation of the modern Grapevine Range fault block. Although no direct constraints exist, I postulate that these faults are remnants of the earliest Eocene-Oligocene, phase of extension.

The Moonlight Canyon fault places Middle Cambrian Nopah Formation in the hanging wall of the Grapevine thrust against Mississippian strata in the footwall of the Grapevine thrust, yielding a minimum throw of $1.5-2 \mathrm{~km}$, assuming that the Zabriskie Quartzite is the lowest stratigraphic unit carried in the hanging wall of the Grapevine thrust. Displacement on the west-dipping fault east of Mt. Palmer is difficult to constrain. However, the fault to the west of Mt. Palmer has a displacement of $\sim 800 \mathrm{~m}$.

\section{Fall Canyon Fault Zone}

The Fall Canyon fault zone is named for exposures to the east of Fall Canyon, which the fault parallels through much of the central Grapevine Mountains (Plate 1; Reynolds, 1969, 1974). This fault zone is a distinct boundary in the Grapevine Mountains, separating Cenozoic volcanic and sedimentary strata to the east from Paleozoic miogeoclinal strata to the west (Plate 1). Both the age and amount of displacement on the Fall Canyon fault zone are difficult to determine. Volcanic rocks as young as 10.4 Ma (Trachyte of Donovan Mountain, Eng et al., 1996) are cut by the fault. On the other hand, more than $2 \mathrm{~km}$ of ignimbrite sheets on the eastern, hanging wall side of the Fall Canyon fault zone are absent on the footwall side of the fault. These ignim- brite sheets are as old as $13.25 \mathrm{Ma}$ (Bullfrog Tuff; Sawyer et al., 1994), suggesting that the Fall Canyon fault zone maintained a significant topographic escarpment in middle Miocene time. One possibility is that the Fall Canyon fault zone was originally active during late Oligocene extension, then reactivated during the early middle Miocene, and remained active until the late Miocene. The Fall Canyon fault zone is overlain by the Rhyolite of Sarcobatus Flat (C.J. Fridrich, unpublished data), placing a lower bound on motion on this fault. A dearth of exposure of Paleozoic strata in the hanging wall of the Fall Canyon fault zone makes estimating offset difficult. If the assumption that the Fall Canyon fault zone was a topographic escarpment in middle Miocene time is valid, then the total thickness of Cenozoic strata in the hanging wall of the fault can provide a minimum constraint on the amount of normal separation on the fault. Using such a proxy yields a minimum separation of $\sim 3 \mathrm{~km}$.

\section{Grapevine Fault Zone}

The Grapevine fault zone (Reynolds, 1969; Applegate, 1995) is a west-dipping fault zone located along the western margin (Death Valley side) of the Grapevine Mountains. This fault zone is best developed south of Titus Canyon along the range front, but steps away from the bedrock-alluvium contact north of Titus Canyon, and is predominantly expressed as east- and west-dipping normal faults cutting alluvial sediments between the range front and the Northern Death Valley fault zone (Plate 1). The total displacement on this fault isn't determinable from available field data. Gravity data, however, indicate that a sedimentary basin as much as $4 \mathrm{~km}$ deep lies just west of the Grapevine Mountains (Blakely et al., 1999). This suggests that throw on the Grapevine fault system may be significant. The age of the Grapevine fault system is also poorly constrained. An ash-fall tuff that is intercalated with sediments that conformably onlap the range front yields a (U-Th)/He age on zircon of 3.09 Ma (Table 1). Fault traces of the Grapevine fault zone, however, clearly cut postPliocene gravels. The Grapevine fault zone was likely active as a major range-bounding fault in late Miocene and Pliocene time. Since that time, the Death Valley basin has probably been largely passively infilling.

\section{Northern Death Valley Fault}

The Northern Death Valley fault is a dextral strike-slip fault that extends over $100 \mathrm{~km}$, from Furnace Creek to Fish Lake Valley. Initially recognized by Curry (1938), it was first described in detail by Noble and Wright (1954). The Northern Death Valley fault strikes sub-parallel to the western range front of the Grapevine Mountains across alluvial fans (Plate 1) and eventually intersects the edge of the mountain range near Scotty's Castle. Spectacular offsets along the fault are observed in the fans west of the Grapevine Mountains, particularly at the mouth of Red Wall Canyon (Brogan et al., 1991; Klinger and Piety, 2000; Frankel et al., 2007). The age of, and offset along, the Northern Death Valley fault are open to debate. Early estimates ranged from $8 \mathrm{~km}$ (Wright and Troxel, 1957) to $70 \mathrm{~km}$ (Stewart, 1967). An offset 

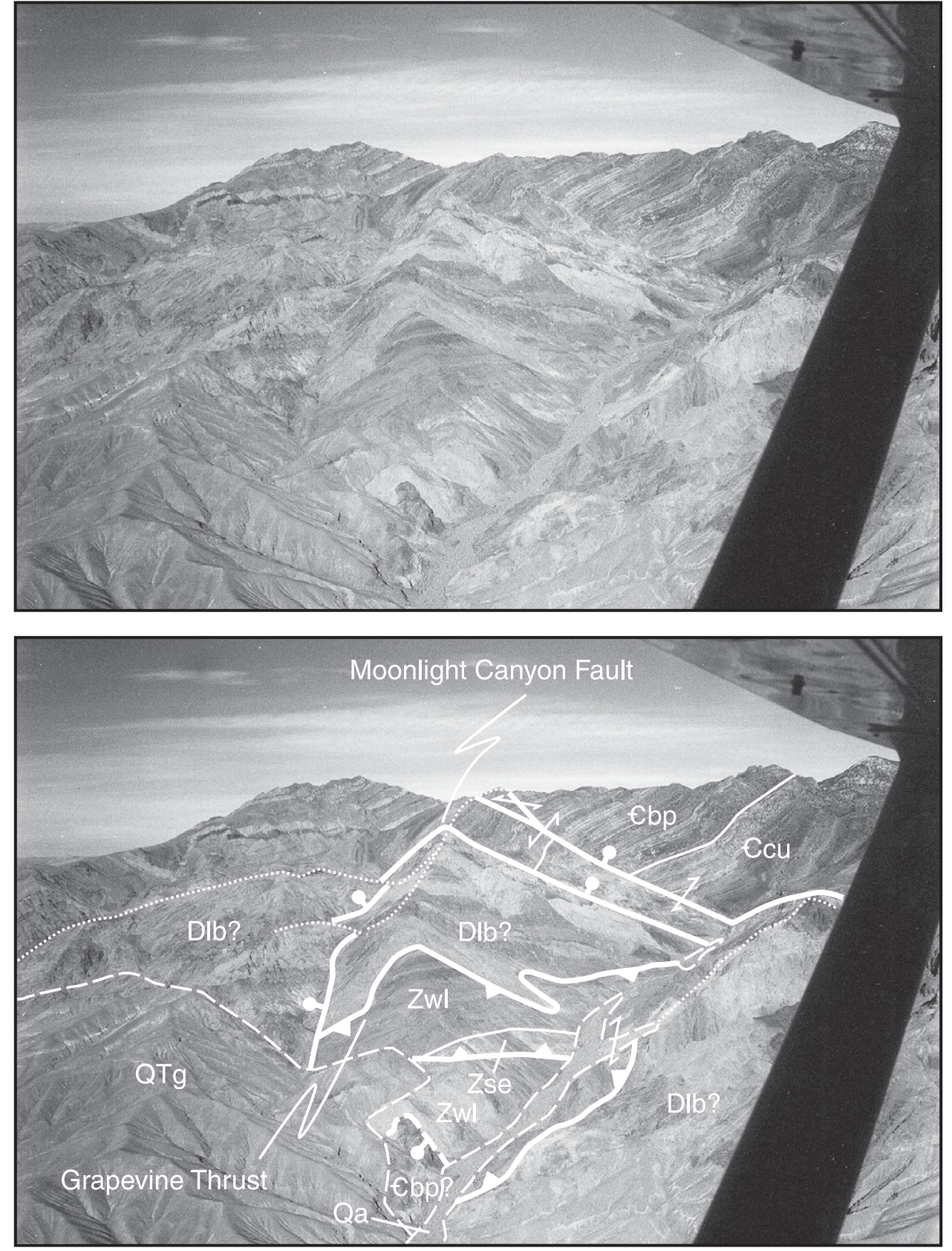

Figure 15. The Moonlight Canyon fault places the hanging wall of the Grapevine thrust down against folded footwall and hanging wall strata of the Grapevine thrust. Looking to the north-northeast, this locality shows the largest stratigraphic throw on the Grapevine thrust in the Grapevine Mountains, where it places upper Stirling Quartzite over Mississippian shales and limestones. Unit abbreviations as on Plate 1. Dotted lines are ridge lines. pluton was used to constrain the total slip on the Northern Death Valley fault to $45 \mathrm{~km}$ (McKee, 1968). Another constraint on slip involves the footwall ramp of the Grapevine thrust. This thrust ramp was previously interpreted as the main footwall ramp of the Grapevine thrust system (Snow and Wernicke, 2000). A structural equivalent to this footwall ramp was proposed to lie in the Cottonwood Mountains, on the western side of the Northern Death Valley fault. Restoring the Northern Death Valley fault such that the two segments of footwall ramp don't overlap requires at least $63 \mathrm{~km}$ of dextral offset (Snow and Wernicke, 2000). If the interpretation of the footwall ramp to the Grapevine thrust presented above is correct, however, then the ramp is due to local structural interactions between the Grapevine thrust and the Titus Canyon anticline and is not the main footwall ramp of the thrust system. In this case, overlap of the two ramps is permissible, and no longer provides a constraint on offset along the Northern Death Valley fault. This leaves the offset pluton (McKee, 1968) as the best estimate of total motion on the Northern Death Valley fault.

The timing of initiation of the Northern Death Valley fault is presumably related to the opening of the Furnace Creek basin at the southern terminus of the fault. Although this basin has long been considered to be middle Miocene in age (Cemen et al., 
1985, 1999; Cemen and Wright, 1988), more recent stratigraphic studies indicate that the Furnace Creek basin opened after $9 \mathrm{Ma}$ (Greene, 1997; Niemi et al., 2001). This suggests that the Northern Death Valley fault is of late Miocene to recent age. Alluvial fans offset by the Northern Death Valley fault zone that have been dated by cosmogenic nuclide dating indicate a slip-rate of $\sim 4 \mathrm{~mm} / \mathrm{yr}$ on this fault (Frankel et al., 2007).

\section{ACKNOWLEDGMENTS}

This research was funded by National Science Foundation grant EAR-9614780 to Brian Wernicke, and an NSF graduate fellowship (NAN). Field work in the Grapevine Mountains would not have been possible without assistance from the Resources Management Office at Death Valley National Park, to whom I am indebted for granting a research permit and arranging permission for helicopter access to the remotest portions of the range. Field assistance was ably provided by Aviva Sussman, Neil Niemi, Wendy Lagerquist, Katra Andreini, Dana Loebman, and Sarah Kopke. John Kelly of El Aero Helicopters and Mark Berry, National Park Service mule packer, provided invaluable logistical support. Discussions and field excursions with Mark Abolins, Rob Brady, Pat Cashman, James Cole, J. Kent Snow, Jim Trexler, and Brian Wernicke contributed significantly to the ideas and interpretations presented here. Chris Fridrich's generosity in the field in discussing and clarifying the volcanic stratigraphy of the map region was extraordinary. He also provided a review that greatly improved the clarity of this report.

\section{REFERENCES CITED}

Albers, J.P., and Stewart, J.H., 1972, Geology and mineral deposits of Esmeralda County, Nevada: Nevada Bureau of Mines and Geology Bulletin 78, $80 \mathrm{p}$.

Applegate, D., 1995, Transform-normal extension on the Northern Death Valley fault system, California-Nevada: Basin Research, v. 7, p. 269-280.

Barnes, H., and Palmer, A.R., 1961, Revision of stratigraphic nomenclature of Cambrian rocks, Nevada Test Site and vicinity: U.S. Geological Survey Professional Paper, v. 424-C, p. C100-C103.

Blakely, R.J., Jachens, R.C., Calzia, J.P., and Langenheim, V.E., 1999, Cenozoic basin of the Death Valley extended terrane as reflected in regionalscale gravity anomalies, in Wright, L.A., and Troxel, B.W., eds., Cenozoic basins of the Death Valley region: Geological Society of America Special Paper 333, p. 1-16.

Brogan, G.E., Kellogg, K.S., Slemmons, D.B., and Terhune, C.L., 1991, Late Quaternary faulting along the Death Valley-Furnace Creek fault system, California and Nevada: U.S. Geological Survey Bulletin 1991, 23 p.

Burchfiel, B.C., 1969, Structural geology of the Dry Mountain Quadrangle, Inyo County, California: California Division of Mines and Geology Special Report 99, 19 p.

Burchfiel, B.C., and Davis, G.A., 1972, Structural framework and evolution of the southern part of the Cordilleran orogen, western United States: American Journal of Science, v. 272, p. 97-118, doi:10.2475/ajs.272.2.97.

Byers, F.M., Jr., Carr, W.J., Christiansen, R.L., Lipman, P.W., Orkild, P.P., and Quinlivan, W.D., 1976a, Geologic map of the Timber Mountain caldera area, Nye County, Nevada: U.S. Geological Survey Miscellaneous Investigations Series Map I-891, scale 1:48,000.

Byers, F.M., Jr., Carr, W.J., Orkild, P.P., Quinlivan, W.D., and Sargent, K.A., 1976b, Volcanic suites and related cauldrons of Timber Mountain-Oasis Valley caldera complex, southern Nevada: U.S. Geological Survey Professional Paper 919, 70 p.
Carr, W.J., and Quinlivan, W.D., 1966, Geologic map of the Timber Mountain quadrangle, Nye County, Nevada: U.S. Geological Survey Geologic Quadrangle Map GQ-503, scale 1:24,000.

Carr, W.J., Byers, F.M., Jr., and Orkild, P.P., 1986, Stratigraphic and volcanotectonic relations of Crater Flat Tuff and some older volcanic units, Nye County, Nevada: U.S. Geological Survey Professional Paper 1323, 28 p.

Cemen, I., and Wright, L.A., 1988, Stratigraphy and chronology of the Artist Drive Formation, Furnace Creek basin, Death Valley, California in Gregory, J.L., and Baldwin, E.J., eds., Geology of the Death Valley region: South Coast Geological Society, 1988 field trip: Santa Ana, California, South Coast Geological Society, p. 77-87.

Cemen, I., Wright, L.A., Drake, R.E., and Johnson, F.C., 1985, Cenozoic sedimentation and sequence of deformational events at the southeastern end of Furnace Creek strike-slip fault-zone, Death Valley region, California, in Biddle, K.T., and Christie-Blick, N., eds., Strike-slip deformation, basin formation, and sedimentation: San Antonio, Texas, United States, Society of Economic Paleontologists and Mineralogists Special Publication 37, p. 127-139.

Cemen, I., Wright, L.A., and Prave, A.R., 1999, Stratigraphy and tectonic implications of the latest Oligocene and early Miocene sedimentary succession, southernmost Funeral Mountains, Death Valley region, California, in Wright, L.A., and Troxel, B.W., eds., Cenozoic basins of the Death Valley region: Geological Society of America Special paper 333, p. 65-86.

Christiansen, R.L., and Barnes, H., 1966, Three members of the Upper Cambrian Nopah Formation in the southern Great Basin: U.S. Geological Survey Bulletin, v. 1244-A, p. A49-A52.

Christiansen, R.L., and Lipman, P.W., 1965, Geologic map of the Topopah Spring NW Quadrangle, Nye County, Nevada: U.S. Geological Survey Geologic Quadrangle, Map GQ-444, scale 1:24,000.

Connors, K.A., Weiss, S.I., and Noble, D., 1998, Geologic map of the northeastern Bullfrog Hills and vicinity, southern Nye County, Nevada: Nevada Bureau of Mines and Geology Map 112, scale 1:24,000, 12 p. text.

Cornwall, H.R., 1972, Geology and mineral deposits of southern Nye County, Nevada: Nevada Bureau of Mines and Geology Bulletin 77, 49 p.

Cornwall, H.R., and Kleinhampl, F.J., 1961, Geology of the Bare Mountain Quadrangle, Nevada: U.S. Geological Survey Geologic Quadrangle Map GQ-157, scale 1:62,500.

Cornwall, H.R., and Kleinhampl, F.J., 1964, Geology of Bullfrog Quadrangle and ore deposits related to Bullfrog Hills caldera, Nye County, Nevada, and Inyo County, California: U.S. Geological Survey Professional Paper 454-J, $25 \mathrm{p}$.

Curry, H.D., 1938, Strike-slip faulting in Death Valley, California: Geological Society of America Bulletin, v. 49, p. 1874-1875.

Dunne, G.C., 1986, Mesozoic evolution of the southern Inyo Mountains, Darwin Plateau, and Argus and Slate Ranges, in Dunne, G.C., ed., Mesozoic and Cenozoic structural evolution of selected areas, east-central California: Los Angeles, Department of Geology, California State University, p. 3-43.

Dunne, G.C., Gulliver, R.M., and Stevens, C.H., 1981, Correlation of Mississippian shelf- to-basin strata, eastern California: Geological Society of America Bulletin, v. 92, no. 1, part II, p. 1-38, doi:10.1130/GSAB -P2-92-1.

Eng, T., Boden, D.R., Reischman, M.R., and Biggs, J.O., 1996, Geology and mineralization of the Bullfrog Mine and vicinity, Nye County, Nevada, in Coyner, A.R., and Fahey, P.L., eds., Geology and ore deposits of the American Cordillera: Geological Society of Nevada Symposium Proceedings, v. 1 , p. $353-402$.

Farley, K.A., 2000, Helium diffusion from apatite: general behavior as illustrated by Durango fluorapatite: Journal of Geophysical Research, v. 105, p. 2903-2914, doi:10.1029/1999JB900348.

Frankel, K.L., Brantley, K.S., Dolan, J.F., Finkel, R.C., Klinger, R.E., Knott, J.R., Machette, M.N., Owen, L.A., Phillips, F.M., and Slate, J.L., 2007, Cosmogenic ${ }^{10} \mathrm{Be}$ and ${ }^{36} \mathrm{Cl}$ geochronology of offset alluvial fans along the northern Death Valley fault zone: Implications for transient strain in the eastern California shear zone: Journal of Geophysical Research, v. 112, B06407, 18 p., doi:10.1029/2006JB004350.

Fridrich, C.J., and Thompson, R.A., 2011, Cenozoic tectonic reorganizations of the Death Valley region, southeast California and southwest Nevada: U.S. Geological Survey Professional Paper 1783, 36 p.

Gebhardt, C., and Willis, T., 1996, Backpacking Death Valley, 3rd edition: San Jose, California, Mastergraphics, $122 \mathrm{p}$.

Gordon, M., Jr., 1964, California Carboniferous cephalopods: U.S. Geological Survey Professional Paper, v. 483-A, p. A1-A27. 
Greene, R.C., 1997, Geology of the northern Black Mountains, Death Valley, California: U.S. Geological Survey Open-file Report 97-79, 110 p.

Hague, A., 1883, Abstract of report on the geology of the Eureka district: U.S. Geological Survey 3rd Annual Report, p. 237-272.

Hazzard, J.C., 1937, Paleozoic section in the Nopah and Resting Spring Mountains, Inyo County, California: California Journal of Mines and Geology, v. 33 , p. $273-339$.

Hazzard, J.C., and Mason, J.F., 1936, Middle Cambrian formations of the Providence and Marble Mountains, California: Geological Society of America Bulletin, v. 47, p. 229-240.

Hinrichs, E.N., and Orkild, P.P., 1961, Eight members of the Oak Spring Formation, Nevada Test Site and vicinity, Nye and Lincoln Counties, Nevada: U.S. Geological Survey Professional Paper 424-D, p. D96-D103.

Hintze, L.F., 1951, Lower Ordovician detailed stratigraphic sections for western Utah: Utah Geological and Mineralogical Survey Bulletin 39, 100 p.

Hudson, M.R., Sawyer, D.A., and Warren, D.A., 1994, Paleomagnetism and rotation constraints for the middle Miocene southwestern Nevada volcanic field: Tectonics, v. 13, p. 258-277, doi:10.1029/93TC03189.

Hunt, C.B., and Mabey, D.R., 1966, Stratigraphy and structure, Death Valley, California: U.S. Geological Survey Professional Paper 494-A, 162 p.

Johnson, E.A., 1971, Geology of part of the southeastern side of the Cottonwood Mountains, Death Valley, California [Ph.D. thesis]: Rice University, Houston, Texas, $81 \mathrm{p}$.

Kirk, E., 1933, The Eureka Quartzite of the Great Basin region: American Journal of Science, 5th Series, v. 26, p. 27-44.

Klinger, R.E., and Piety, L.A., 2000, Late quaternary tectonic activity on the Death Valley and Furnace Creek faults, Death Valley, California: U.S. Geological Survey Digital Data Series DDS-58, 16 p., http://geology .cr.usgs.gov/pub/dds/dds-058/Ch_H.pdf.

Langenheim, R.L., and Tischler, H., 1960, Mississippian and Devonian paleontology and stratigraphy, Quartz Spring area, Inyo County, California: University of California Publications in Geological Sciences, v. 38, p. 89-152.

Lipman, P.W., and Christiansen, R.L., 1964, Zonal features of an ash-flow sheet in the Piapi Canyon Formation, southern Nevada: U.S. Geological Survey Professional Paper, v. 601-B, p. B74-B78.

Lipman, P.W., Christiansen, R.L., and O'Connor, J.T., 1966a, A compositionally zoned ash-flow sheet in southern Nevada: U.S. Geological Survey Professional Paper, v. 524-F, p. F1-F47.

Lipman, P.W., Quinlivan, W.D., Carr, W.J., and Anderson, R.E., 1966b, Geologic map of the Thirsty Canyon SE quadrangle, Nye County, Nevada: U.S. Geological Survey Geologic Quadrangle Map GQ-489, scale $1: 24,000$

Maldonado, F., 1990a, Structural geology of the upper plate of the Bullfrog Hills detachment fault system, southern Nevada: Geological Society of America Bulletin, v. 102, p. 992-1006, doi:10.1130/0016-7606(1990)102 $<0992$ :SGOTUP>2.3.CO;2.

Maldonado, F., 1990b, Geologic map of the northwest quarter of the Bullfrog $15^{\prime}$ quadrangle, Nye County, Nevada: U.S. Geological Survey Miscellaneous Investigations Series Map I-1985, scale 1:24,000.

Maldonado, F., and Hausback, B.P., 1990, Geologic map of the northeast quarter of the Bullfrog $15^{\prime}$ quadrangle, Nye County, Nevada: U.S. Geological Survey Miscellaneous Investigations Series Map I-2049, scale 1:24,000.

McAllister, J.F., 1952, Rocks and structure of the Quartz Spring area, northern Panamint Range, California: California Division of Mines and Geology Special Report 25, 38 p.

McAllister, J.F., 1955, Geology of mineral deposits in the Ubehebe Peak quadrangle, Inyo County, California: California Division of Mines and Geology Special Report 42, 63 p.

McAllister, J.F., 1974, Silurian, Devonian, and Mississippian formations of the Funeral Mountain in the Ryan quadrangle, Death Valley region, California: U.S. Geological Survey Bulletin 1386, 35 p.

McKee, E.H., 1968, Age and rate of movement on the northern part of the Death Valley-Furnace Creek fault zone, California: Geological Society of America Bulletin, v. 79, p. 509-512, doi:10.1130/0016-7606(1968)79[509: AAROMO]2.0.CO;2.

Miller, R.H., 1976, Revision of Upper Ordovician, Silurian, and Lower Devonian stratigraphy, southwestern Great Basin: Geological Society of America Bulletin, v. 87, p. 961-968, doi:10.1130/0016-7606(1976)87<961: ROUOSA $>2.0 . \mathrm{CO} ; 2$.

Miller, R.H., 1978, Early Silurian to Early Devonian conodant biostratigraphy and depositional environments of the Hidden Valley Dolomite, southeastern California: Journal of Paleontology, v. 52, p. 323-344.
Miller, R.H., and Walch, C.A., 1977, Depositional environments of Upper Ordovician through Lower Devonian rocks in the southern Great Basin, in Stewart, J.H., Stevens, C.H., and Fritsche, A.E., eds., Paleozoic paleogeography of the western United States; Pacific Coast Paleogeography Symposium I: Society of Economic Paleontologists and Mineralogists, p. 165-180.

Minor, S.A., Sawyer, D.A., Wahl, R.R., Frizzell, V.A., Schilling, S.P., Warren, R.G., Orkild, P.P., Coe, J.A., Hudson, M.R., Fleck, R.J., Lanphere, M.A., Swadley, W.C., and Cole, J.C., 1993, Preliminary geologic map of the Pahute Mesa $30^{\prime} \times 60^{\prime}$ quadrangle: U.S. Geological Survey Open-file Report 93-299, scale 1:100,000.

Monsen, S.A., Carr, M.D., Reheis, M.C., and Orkild, P.P., 1992, Geologic map of Bare Mountain, Nye County, Nevada: U.S. Geological Survey Miscellaneous Investigations Map I-2201, scale 1:24,000, 6 p. text.

Niemi, N.A., Wernicke, B.P., Brady, R., Saleeby, J., and Dunne, G.C., 2001, Distribution and provenance of the middle Miocene Eagle Mountain formation, and implications for regional kinematic analysis of the Basin and Range province: Geological Society of America Bulletin, v. 113, p. 419442, doi:10.1130/0016-7606(2001)113<0419:DAPOTM>2.0.CO;2.

Noble, D.C., Weiss, S.I., and McKee, E.H., 1991, Caldera geology, magmatic and hydrothermal activity and regional extension in the western part of the southwestern Nevada volcanic field, in Raines, G.L., Lisle, R.E., Shafer, R.W., and Wilkinson, W.W., eds., Geology and ore deposits of the Great Basin: Geological Society of Nevada Symposium Proceedings, v. 2, p. 913-934.

Noble, L.F., and Wright, L.A., 1954, Geology of the central and southern Death Valley region, California, in Jahns, R.H., ed., Geology of southern California: California Division of Mines and Geology Bulletin, v. 170, p. $143-160$

Nolan, T.B., 1929, Notes on the stratigraphy and structure of the northwestern portion of Spring Mountain, Nevada: American Journal of Science, series 5 , v. 17, p. 461-472, doi:10.2475/ajs.s5-17.101.461.

Nolan, T.B., Merriam, C.W., and Williams, J.S., 1956, The stratigraphic section in the vicinity of Eureka, Nevada: U.S. Geological Survey Professional Paper 276, $77 \mathrm{p}$.

Orkild, P.P., 1965, Paintbrush Tuff and Timber Mountain Tuff of Nye County, Nevada, in Cohee, G.V. and West, W.S., Changes in stratigraphic nomenclature by the U.S. Geological Survey, 1964: U.S. Geological Survey Bulletin 1224-A, p. A44-A51.

Palmer, A.R., 1965, Trilobites of the Late Cambrian Pterocephaliid Biomere in the Great Basin, United States: U.S. Geological Survey Professional Paper 4983, $105 \mathrm{p}$.

Palmer, A.P., and Halley, R.B., 1979, Physical stratigraphy and trilobite biostratigraphy of the Carrara Formation (Lower and Middle Cambrian) in the southern Great Basin: U.S. Geological Survey Professional Paper 1047, $131 \mathrm{p}$.

Palmer, A.P., and Hazzard, J.C., 1956, Age and correlation of Cornfield Springs and Bonanza King formations in southeastern California and southern Nevada: The American Association of Petroleum Geologists Bulletin, v. 40, p. $2494-2499$.

Pelton, P.J., 1966, Mississippian rocks of the southwestern Great Basin, Nevada and California [Ph.D. thesis]: Rice University, Houston, Texas, 146 p.

Poole, F.G., and McKeown, F.A., 1962, Oak Spring Group of the Nevada Test Site and vicinity: U.S. Geological Survey Professional Paper 450-C, p. C60-C62.

Poole, F.G., and Sandberg, C.A., 1977, Mississippian paleogeography and tectonics of the western United States, in Stewart, J.H., Stevens, C.H., and Fritsche, A.E., eds., Paleozoic paleogeography of the western United States; Pacific Coast Paleogeography Symposium I: Society of Economic Paleontologists and Mineralogists, p. 67-86.

Poole, F.G., Sandberg, C.A., and Boucot, A.J., 1977, Silurian and Devonian paleogeography of the western United States, in Stewart, J.H., Stevens, C.H., and Fritsche, A.E., eds., Paleozoic paleogeography of the western United States; Pacific Coast Paleogeography Symposium I: Society of Economic Paleontologists and Mineralogists, p. 39-66.

Ransome, F.L., Emmons, W.H., and Garrey, G.H., 1910, Geology and ore deposits of the Bullfrog district, Nevada: U.S. Geological Survey Bulletin $407,130 \mathrm{p}$.

Reynolds, M.W., 1969, Stratigraphy and structural geology of the Titus and Titanothere canyons area, Death Valley, California [Ph.D. thesis]: Berkeley, University of California, $310 \mathrm{p}$.

Reynolds, M.W., 1974, Geology of the Grapevine Mountains, Death Valley, California; a summary, in Death Valley region, California and Nevada, 
Geological Society of America Cordilleran Section, Field Trip 1 Guidebook, Death Valley Publishing Company, Shoshone, California, p. 91-97.

Ross, D.C., 1967, Generalized geologic map of the Inyo Mountains region, California: U.S. Geological Survey Miscellaneous Investigations Series Map I-506, scale 1:125,000.

Ross, R.J., 1964, Middle and Lower Ordovician formations in southernmost Nevada and adjacent California: U.S. Geological Survey Bulletin 1180-C, p. C1-C101.

Ross, R.J., 1977, Ordovician paleogeography of the western United States, in Stewart, J.H., Stevens, C.H., and Fritsche, A.E., eds., Paleozoic paleogeography of the western United States; Pacific Coast Paleogeography Symposium I: Society of Economic Paleontologists and Mineralogists, p. 19-38.

Sawyer, D.A., Fleck, R.J., Lanphere, M.A., Warren, R.G., Broxton, D.E., and Hudson, M.R., 1994, Episodic caldera volcanism in the Miocene southwestern Nevada volcanic field; revised stratigraphic framework, ${ }^{40} \mathrm{Ar} /{ }^{39} \mathrm{Ar}$ geochronology, and implications for magmatism and extension: Geological Society of America Bulletin, v. 106, p. 1304-1318, doi:10.1130/0016 -7606(1994)106<1304:ECVITM>2.3.CO;2.

Saylor, B.Z., 1991, The Titus Canyon Formation: Evidence for early Oligocene extension in the Death Valley area, California [M.S. thesis]: Massachusetts Institute of Technology, Cambridge, $65 \mathrm{p}$.

Saylor, B.Z., and Hodges, K.V., 1994, ${ }^{40} \mathrm{Ar} /{ }^{39} \mathrm{Ar}$ age constraints on the depositional history of the Oligocene Titus Canyon Formation, Death Valley, California: Geological Society of America Abstracts with Programs, v. 26 , no. 2 , p. 88.

Slate, J.L., Berry, M.E., Rowley, P.D., Fridrich, C.J., Morgan, K.S., Workman, J.B., Young, O.D., Dixon, G.L., Williams, V.S., McKee, E.H., Ponce, D.A., Hildenbrand, T.G., Swadley, W.C., Lundstrom, S.C., Ekren, E.B., Warren, R.G., Cole, J.C., Fleck, R.J., Lanphere, M.A., Sawyer, D.A., Minor, S.A., Grunwald, D.J., Laczniak, R.J., Menges, C.M., Yount, J.C., and Jayko, A.S., 1999, Digital geologic map of the Nevada Test Site and vicinity, Nye, Lincoln, and Clark counties, Nevada, and Inyo County, California: U.S. Geological Survey Open-file Report 99-554-A, scale 1:100,000, 53 p. text.

Snow, J.K., 1990, Cordilleran orogenesis, extensional tectonics, and geology of the Cottonwood Mountains area, Death Valley region, California and Nevada [Ph.D. thesis]: Cambridge, Massachusetts, Harvard University, $533 \mathrm{p}$.

Snow, J.K., 1992, Large-magnitude Permian shortening and continental margin tectonics in the southern Cordillera: Geological Society of America Bulletin, v. 104, p. 80-105, doi:10.1130/0016-7606(1992)104<0080: LMPSAC $>2.3 . \mathrm{CO} ; 2$.

Snow, J.K., and Lux, D.R., 1999, Tectono-sequence stratigraphy of Tertiary rocks in the Cottonwood Mountain and northern Death Valley area, California and Nevada, in Wright, L.A. and Troxel, B.W. eds., Cenozoic basins of the Death Valley region: Geological Society of America Special Paper 333, p. 17-64.

Snow, J.K., and Wernicke, B.P., 1989, Uniqueness of geological correlations; an example from the Death Valley extended terrain: Geological Society of America Bulletin, v. 101, p. 1351-1362, doi:10.1130/0016 -7606(1989)101<1351:UOGCAE>2.3.CO;2.

Snow, J.K., and Wernicke, B.P., 2000, Cenozoic tectonism in the central Basin and Range; magnitude, rate, and distribution of upper crustal strain: American Journal of Science, v. 300, p. 659-719, doi:10.2475/ajs.300.9.659.

Snow, J.K., and White, C., 1990, Listric normal faulting and synorogenic sedimentation, northern Cottonwood Mountains, Death Valley region, California, in Wernicke, B.P., ed., Basin and Range extensional tectonics near the latitude of Las Vegas, Nevada: Geological Society of America Memoir 176, p. 413-445.

Snow, J.K., Asmerom, Y., and Lux, D.R., 1991, Permian-Triassic plutonism and tectonics; Death Valley region, California and Nevada: Geology, v. 19, p. 629-632, doi:10.1130/0091-7613(1991)019<0629:PTPATD>2.3.CO;2.

Snow, J.K., Geissman, J.W., and Wernicke, B., 1993, Paleomagnetic data from Paleozoic sedimentary rocks and Permo-Triassic intrusions, Death Valley area, southeast California; implications for Mesozoic and Cenozoic deformation: Eos (Transactions, American Geophysical Union), v. 74, p. 206.
Stadler, C.A., 1968, The geology of the Goldbelt Spring area, northern Panamint Range, Inyo County, California [Ph.D. thesis]: Cambridge, Massachusetts Institute of Technology, $183 \mathrm{p}$.

Stevens, C.H., 1986, Evolution of the Ordovician through Middle Pennsylvanian carbonate shelf in east-central California: Geological Society of America Bulletin, v. 97, p. 11-25, doi:10.1130/0016-7606(1986)97<11:EOTOTM $>2.0 . \mathrm{CO} ; 2$.

Stevens, C.H., and Stone, P., 1988, Early Permian thrust faults in east-central California: Geological Society of America Bulletin, v. 100, p. 552-562, doi:10.1130/0016-7606(1988)100<0552:EPTFIE>2.3.CO;2.

Stevens, C.H., and Stone, P., 2002, Correlation of Permian and Triassic deformations in the western Great Basin and eastern Sierra Nevada: Evidence from the northern Inyo Mountains near Tinemaha Reservoir, east-central California: Geological Society of America Bulletin, v. 114, p. 1210-1221, doi:10.1130/0016-7606(2002)114<1210:COPATD >2.0.CO;2.

Stevens, C.H., and Stone, P., 2005a, Interpretation of the Last Chance thrust, Death Valley region, California, as an Early Permian décollement in a previously undeformed shale basin: Earth-Science Reviews, v. 73, p. 79-101, doi:10.1016/j.earscirev.2005.04.005.

Stevens, C.H., and Stone, P., 2005b, Structure and regional significance of the Late Permian(?) Sierra Nevada-Death Valley thrust system, east-central California: Earth-Science Reviews, v. 73, p. 103-113, doi:10.1016/j.earscirev .2005.04.006.

Stewart, J.H., 1967, Possible large right-lateral displacement along fault and shear zones in the Death Valley-Las Vegas area, California and Nevada: Geological Society of America Bulletin, v. 78, p. 131-142, doi: 10.1130/0016-7606(1967)78[131:PLRDAF]2.0.CO;2.

Stewart, J.H., 1970, Upper Precambrian and Lower Cambrian strata in the southern Great Basin California and Nevada: U.S. Geological Survey Professional Paper 620, 206 p.

Stewart, J.H., and Suczek, C.A., 1977, Cambrian and latest Precambrian paleogeography and tectonics in the western United States, in Stewart, J.H., Stevens, C.H., and Fritsche, A.E., eds., Paleozoic paleogeography of the western United States; Pacific Coast Paleogeography Symposium I: Society of Economic Paleontologists and Mineralogists, p. 19-38.

Stock, C., and Bode, F.D., 1935, Occurrence of lower Oligocene mammal bearing beds near Death Valley, California: Proceedings of the National Academy of Sciences of the United States of America, v. 21, p. 571-579, doi:10.1073/pnas.21.10.571

Stone, P., 1984, Stratigraphy, depositional history, and paleogeographic significance of Pennsylvanian and Permian rocks in the Owens Valley-Death Valley region, California [Ph.D. thesis]: Stanford University, Palo Alto, California, $339 \mathrm{p}$.

Strand, R.G., compiler, 1967, Geologic map of California, Mariposa sheet: California Division of Mines and Geology, scale 1:250,000.

Streitz, R., and Stinson, M.C., compilers, 1974, Geologic map of California, Death Valley sheet: California Division of Mines and Geology, scale 1:250,000.

Trexler, J.H., Jr., Cole, J.C., and Cashman, P.H., 1996, Middle Devonian-Mississippian stratigraphy on and near the Nevada Test Site; implications for hydrocarbon potential: The American Association of Petroleum Geologists Bulletin, v. 80, p. 1736-1762.

Westgate, L.G., and Knopf, A., 1932, Geology and ore deposits of the Pioche district, Nevada: U.S. Geological Survey Professional Paper 171, 79 p.

Wright, L.A., and Troxel, B.W., 1967, Limitations on right-lateral, strikeslip displacement, Death Valley and Furnace Creek fault zones, California: Geological Society of America Bulletin, v. 78, p. 933-950, doi: 10.1130/0016-7606(1967)78[933:LORSDD]2.0.CO;2.

Wright, L.A., and Troxel, B.W., 1993, Geologic map of the central and northern Funeral Mountains and adjacent areas, Death Valley region, Southern California: U.S. Geological Survey Miscellaneous Investigations Series Map I-2305, scale 1:48,000.

Zenger, D.H., and Pearson, E.F., 1969, Stratigraphy and petrology of the Lost Burro Formation, Panamint Range, California: California Division of Mines and Geology Special Report 100, p. 45-66.

Manuscript Accepted by the Society 14 August 2012 